University of Louisville

ThinkIR: The University of Louisville's Institutional Repository

Electronic Theses and Dissertations

$12-2018$

\title{
Furthering understanding of forensic units: a detailed examination of Knoxville police department's crime scene unit.
}

Cassandra Christina Rausch

University of Louisville

Follow this and additional works at: https://ir.library.louisville.edu/etd

Part of the Criminology and Criminal Justice Commons

\section{Recommended Citation}

Rausch, Cassandra Christina, "Furthering understanding of forensic units: a detailed examination of Knoxville police department's crime scene unit." (2018). Electronic Theses and Dissertations. Paper 3113. https://doi.org/10.18297/etd/3113

This Doctoral Dissertation is brought to you for free and open access by ThinkIR: The University of Louisville's Institutional Repository. It has been accepted for inclusion in Electronic Theses and Dissertations by an authorized administrator of ThinkIR: The University of Louisville's Institutional Repository. This title appears here courtesy of the author, who has retained all other copyrights. For more information, please contact thinkir@louisville.edu. 
FURTHERING UNDERSTANDING OF FORENSICS UNITS: A DETAILED EXAMINATION OF KNOXVILLE POLICE DEPARTMENT'S CRIME SCENE UNIT

\author{
By \\ Cassandra Christina Rausch \\ B.A., University of Louisville, 2012 \\ M.S., University of Louisville, 2014
}

\begin{abstract}
A Dissertation
Submitted to the Faculty of the

College of Arts and Sciences of the University of Louisville in Partial Fulfillment of the Requirements

for the Degree of
\end{abstract}

Doctor of Philosophy

in Criminal Justice

Department of Criminal Justice

University of Louisville

Louisville, Kentucky

December 2018 
Copyright 2018 by Cassandra Christina Rausch

All rights reserved 

FURTHERING UNDERSTANDING OF FORENSICS UNITS: A DETAILED EXAMINATION OF KNOXVILLE POLICE DEPARTMENT'S CRIME SCENE UNIT

By

Cassandra Christina Rausch

B.A., University of Louisville, 2012

M.S., University of Louisville, 2014

A Dissertation Approved on

November $19^{\text {th }}, 2018$

by the following Dissertation Committee:

Dissertation Chair

Deborah Keeling

Cherie Dawson-Edwards

Viviana Andreescu

Stuart Esrock 


\section{DEDICATION}

This dissertation is dedicated to my daughters

Callandra and Lillian

to show them that no goal is unattainable

and no dream is out of their reach.

"If my mind can conceive it, and my heart can believe it-

I can achieve it."

-Muhammed Ali 


\section{ACKNOWLEDGEMENTS}

I would like to thank my Chair, Dr. Deborah Keeling, for the countless hours, time, and effort she has put into making this research into reality. Without her endless support and encouragement, I would not be where I am today. I would also like to thank my other committee members, Dr. Cherie Dawson-Edwards, Dr. Viviana Andreescu, and Dr. Stuart Esrock, for their time as well as their valuable comments and feedback. Finally, I would like to give thanks to my parents, David Rausch and Constance Heaton Rausch, who have encouraged me to achieve my dreams since I was a child, who have supported me no matter what I have done or where I have been, and who believed in me even when I didn't believe in myself. Thank you all. 


\begin{abstract}
FUTHERING UNDERSTANDING OF FORENSICS UNITS: A DETAILED

EXAMINATION OF KNOXVILLE POLICE DEPARTMENT'S FORENSIC UNIT

Cassandra Christina Rausch
\end{abstract}

November $19^{\text {th }}, 2018$

Throughout the past three decades, the criminal justice system has decidedly employed new technologies for the purposes of establishing guilt or innocence. Forensic science, with its synthesis of scientific methodology and investigative considerations of law enforcement, ushered in the development of DNA profiling and forever changed the process of crime scene investigation. This shift in focus also led to a shift in the individuals involved in investigation, producing the widespread formation of stand-alone crime scene units. Utilizing both civilian and sworn employees of a law enforcement agency, these units became responsible for the documentation, collection, and preservation of evidence that would later make or break a criminal case in the courtroom.

The transition with the increased use of forensic science resulted in a shift in legal approaches and methodologies that began to place more value on physical rather than circumstantial evidence; in due time, "scientific proof" became a necessity in the courtroom and led to an indispensable reliance on crime scene units. Yet, for all the focus placed on forensic science following the advent of DNA profiling, little attention has been given to the crime scene units responsible for this evidence collection and preservation. A lack of national standards for crime scene units and the nature of law 
enforcement organizations in the United States resulted in the independent development of units each with independently developed standard operations, collection procedures, and preservation methods, with no uniform professional standards as to how this crucial evidence should be handled.

The purpose of the current study was to fill this gap through the exploration, collection and analysis of data related to the operations of the forensics unit of the Knoxville Police Department. The data was collected as part of a formative program evaluation with both process and outcome components. Findings from this research were compared to the standards recommended by the National Institute of Justice (2009), as well as to standards developed through prior research on characteristics that resulted in effective crime scene investigation (Kelty, Julian, \& Robertson, 2011; Ludwig, Edgar, \& Maguire, 2014). Lastly, findings of the current research were compared to those of Rausch's (2015) study that assessed the standards, education levels, training, and national certification of forensics units across the United States. Comparing the current and previous data allowed recommendations to be developed that would contribute to improvement in crime scene unit operations.

The program evaluation that sought to identify key components and policies of the unit that contribute to unit effectiveness and efficiency and included both qualitative and quantitative information collected in multiple stages. Perceptions of the "users" of the unit were assessed to determine user perception of the effectiveness of the unit. Additionally, information on the effectiveness and efficiency of unit processes, unit outcomes, and relevant factors that serve to influence unit performance were examined. The evaluation gathered information on these characteristics of the unit and its operations 
and assessed the extent to which the standards in the police unit meet professional forensic standards and recommendations as set forth in the National Institute of Justice (NIJ) report on the status of criminal forensics (National Institute of Justice, 2009).

Additionally, information on the nature of organizational relations as they may affect unit performance were assessed. That is, the nature of relations between officers and civilians in the unit as well as aspects of unit subculture were identified and reviewed. The information collected on the nature of these relations were assessed using standards set forth in the research literature as characteristics of effective forensics units and forensic examiners. Lastly, the information collected on KPD was compared to data collected on a national sample of crime scene units (Rausch, 2015) to determine the extent to which KPD was similar to or different from other crime scene units contained in this survey.

Participants in this study were sworn and civilian employees of the Crime Scene Unit of KPD and sworn patrol personnel within KPD. Data was collected through mixed methods including survey distribution, interviews and observation within the unit. Data was collected from September 1, 2017 to January 31, 2018; follow-up data collection to provide for a more complete analysis was collected from May 1, 2018 through June 30, 2018.

Results indicated that the Crime Scene Unit of KPD was currently operating at a higher standard in comparison to the national recommendations and baseline data collected in prior research (Rausch, 2015). Interpersonal relations within the unit were sound and personnel within the unit were perceived as operating within the context of characteristics that resulted in effective crime scene investigator/unit performance. KPD 
personnel were mostly satisfied with the services provided by the unit. While this was an evaluation of only one forensics unit with small numbers of unit personnel, the model used for evaluation may be applied in other departments, therefore extending the capabilities to oversee, direct and develop forensics units within the context of evidencebased decision making. Recommendations based on the current work included: gathering data that could be used to assess forensics unit effectiveness and the factors that would facilitate or impede the same, movement toward national forensic standards, and use of the current methodology as a template that could be used to evaluate forensic crime units nationwide. 


\section{TABLE OF CONTENTS}

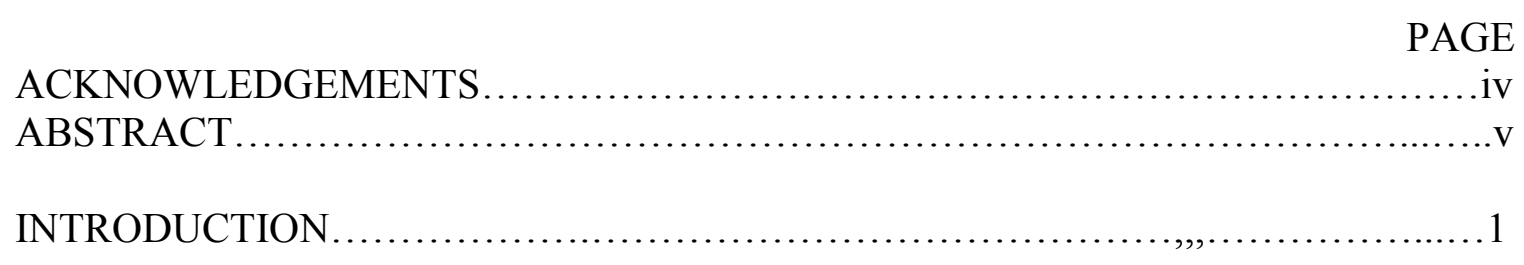

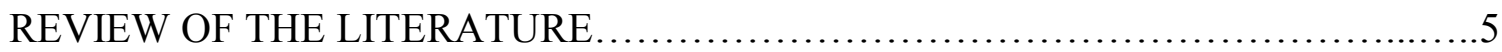

PROGRAM EVALUATION RESEARCH QUESTIONS.............................28

METHODOLOGY ....................................................... 32

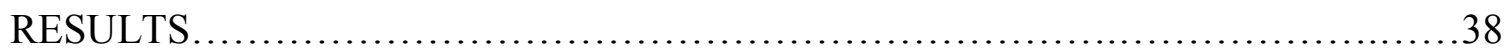

Knoxville Police Department Forensics Unit................................. 38

User Perceptions of the Knoxville Police Department Forensics Unit..............40

Best Practices and Standards...........................................44

Education................................................................. 49

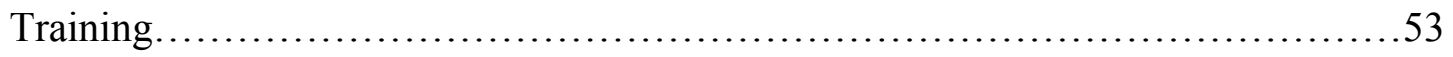

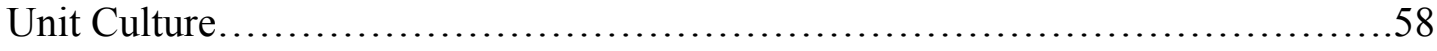

National Sample Comparison..............................................64

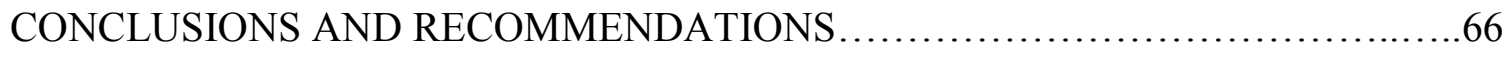

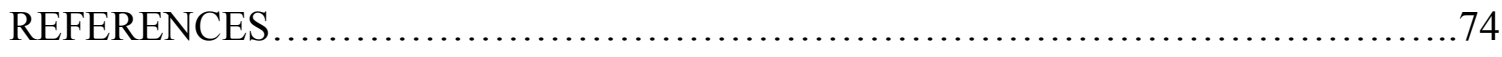

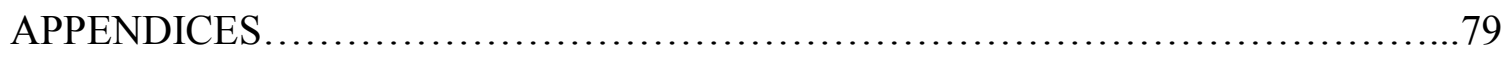

CURRICULUM VITA........................................................ 88 


\section{CHAPTER I}

\section{INTRODUCTION}

Throughout the past three decades, the criminal justice system has decidedly employed new technologies for the purposes of establishing guilt or innocence. Forensic science, with its synthesis of scientific methodology and investigative considerations of law enforcement, ushered in the development of DNA profiling and forever changed the process of crime scene investigation. This shift in focus also led to a shift in the individuals involved in investigation, producing the widespread formation of stand-alone crime scene units. Utilizing both civilian and sworn employees of a law enforcement agency, these units became responsible for the documentation, collection, and preservation of evidence that would later make or break a criminal case in the courtroom.

The transition with the increased use of forensic science resulted in a shift in legal approaches and methodologies that began to place more value on physical rather than circumstantial evidence; in due time, "scientific proof" became a necessity in the courtroom and led to an indispensable reliance on crime scene units. Yet, for all the focus placed on forensic science following the advent of DNA profiling, little attention has been given to the crime scene units responsible for this evidence collection and preservation. A lack of national standards for crime scene units and the nature of law enforcement organizations in the United States resulted in the independent development of units each with independently developed standard operations, collection procedures, 
and preservation methods, with no uniform professional standards as to how this crucial evidence should be handled. More recently, multiple incidents of individuals wrongly convicted through "scientific proof" have been put forth by the media. And, while these wrongful convictions and subsequent exonerations would suggest that "scientific evidence" may not be fool-proof, the expectant nature of jurors and judges alike on forensic evidence continues to rise.

In order to ensure that forensic evidence is documented, collected, and preserved using the best methods possible; the evaluation of crime scene units on a state and/or national level is necessary. Ultimately, this will ensure that those personnel responsible for the forensic evidence are implementing and adhering to the protocols necessary for evidence to be acceptable. However important this research on the quality of forensic evidence collection, preservation and documentation may be, currently there is a large gap in the literature related to the structure, logistics, and daily operations of crime scene units as well as examinations of standards, training and qualifications of personnel within these units. More specifically, no current research exists that attempts to examine and define how the independent operations, staffing, training, etc. meet commonly recognized standards.

In part, this lack of research into the extent to which crime scene units meet appropriate standards of operation is complicated by a lack of clear guiding standards at the national-level. Currently, only standards recommended by National Institute of Justice $(2009,2013)$ exist to promote consistency in crime scene operations nationally. The purpose of the current study is to fill this gap through the exploration, collection and analysis of data related to the operations of the forensics unit of the Knoxville Police 
Department. The data was collected as part of a formative program evaluation with both process and outcome components. Findings from this research were compared to the standards recommended by the National Institute of Justice (2009), as well as to standards developed through prior research on characteristics that resulted in effective crime scene investigation (Kelty, Julian, \& Robertson, 2011; Ludwig, Edgar, \& Maguire, 2014). Lastly, findings of the current research were compared to those of Rausch's (2015) study that assessed the standards, education levels, training, and national certification of forensics units across the United States. Comparing the current and previous data allowed recommendations to be developed that would contribute to improvement in crime scene unit operations.

The program evaluation was formative in that the research was designed to identify both strengths and weaknesses of the unit as a means of improving the efficiency and effectiveness of unit operations. The overall goals for efficient and effective performance included the following: ensuring education levels are appropriate for the work at hand; ensuring that proper, routine, and updated training is being administered and is inclusive of all traditional and interdisciplinary forensic methods; identification of known and followed standards of field investigation that are routinely updated; cooperation between officers and civilians regardless of rank or position; and successful case progression through the system due to sound evidence that results in an appropriate conviction.

These goals were based on the recommendations developed in the National Institute of Justice (2009) publication, "Strengthening Forensic Science in the United States: A Path Forward". Ultimately, the goal was not only to determine whether or not 
changes are necessary for improvement in the KPD crime scene unit, but to provide a methodological framework. This framework could be the beginning of a template for implementation of program evaluations in other crime scene units around the country, with the eventual goal of creating a nationwide database on best practices to facilitate the standardization of crime scene investigation practices. 


\section{CHAPTER II}

\section{REVIEW OF THE LITERATURE}

\section{Program Evaluation}

Engaged scholarship is a term coined by Ernst Boyer (1990). The term refers to a strong linkage between the academy and the community in meaningful ways. While varied terminology has been used to describe this form of research (applied research, public scholarship, engaged scholarship, community-engaged scholarship, action research, translational research, public scholarship), engaged research is defined as "the collaboration between academics and individuals outside the academy - knowledge professionals and the lay public" (Barker 2004). Common elements of engaged research include research based on the reciprocal and mutually beneficial exchange of knowledge, democratic orientation toward non-academics, orientation toward change, and actively encouraging involvement of academics and the public in solutions social problems (Barker, 2004). Engaged scholarship moves from traditional scholarly research to the real-world application of academic research.

One form of engaged scholarship is program evaluation. Program evaluation is a way to monitor and assess the quality and quantity of social programs and initiatives using evidence-based research. The United States Government Accountability Office defines program evaluation as 
"...a systematic study using research methods to collect and analyze data to assess how well a program is working and why. Evaluations answer specific questions about program performance and may focus on assessing program operations or results. Evaluation results may be used to assess a program's effectiveness, identify how to improve performance, or guide resource allocation" (United States Government Accountability Office, 2012, p.3)"

Generally, program evaluations are classified in to three categories, Goals-Based Evaluation, Process-Based Evaluations, and Outcomes-Based Evaluations. Goals-based evaluations use empirical evidence to determine whether programs are meeting their specified goals and, if not, how the program can improve performance. Process-based evaluations are directed toward full understanding of how programs operate, and, if necessary, how these operations can be improved. Lastly, Outcomes-based evaluations focus on the extent to which programs are producing appropriate and effective outcomes and, if not, how the modes of production can be altered to achieve program effectiveness (McNamara, 2017).

Small (2012) states that program evaluation differs from traditional scholarly research in four ways. First, program evaluation focuses on a specific program's performance, while traditional research seeks to produce new knowledge within a field and to generalize findings to a whole population. Second, program evaluation has, as its goal, to improve the program as opposed to proving that the program works. Third, program evaluation determines the value of program operations rather than being valuefree. In other words, while program evaluation is expected to follow evidence-based, scientific research methodology, ultimately the findings are compared to sets of standards and expectations to determine the "value" of the program. In contrast, traditional research ends with the findings produced by the empirical research and does not follow with the 
additional step of comparing the empirical findings with performance standards. Lastly, program evaluations and traditional research ask different research questions. Program evaluation asks whether or not a program is working, while traditional research asks "what worked." Therefore, rather than reporting findings that emphasize conclusions in the present, traditional research "waits for the experiment to play out" and then asks "did it work?".

According to Mears (2010), there are significant problems in the state of research today related to evidence-based policy and lack of guidance in relation to evaluations that could inform and guide widespread policies within the criminal justice system. Within program evaluation, stronger ties between researchers, policy makers, and practitioners are emphasized. To more traditional scholars, this may be viewed as a violation of the requirement of objectivity in scientific research. Nonetheless, evaluation research should be explored and utilized in order for policies to have an evidence-based foundation guided by controlled, quality empirical results. Relatedly, criminal justice policies must come to the point where evaluation research is ingrained as a required and encouraged practice. Improvement to the criminal justice system is a goal of program evaluation along with the incorporation of applied research with basic research that is promulgated as a more traditional scholarly product as a means of strengthening our understanding of the operations of the criminal justice system.

In addition, Mears (2010) addressed the multiple challenges and concerns about the current state of program evaluation and policy research. The author stated that the lack of evidence utilized when creating and implementing criminal justice policies was detrimental to the discipline as a whole, as several studies have suggested that evaluations 
with strong empirical and theoretical foundations would help create sound policy. False dichotomies, transitions from one attitude towards crime to another, overrepresentation of sensationalized cases within policy-making, and response-based implementation lead to the limited production of policy research, creating a barrier influenced by political factors that works against the true nature of applied research academics within the criminal justice discipline.

Interestingly, in a 2017 survey conducted by the U.S. Government Accountability Office, researchers found a failure to utilize empirical-based decision-making was not unique to law enforcement organizations. This survey, based on 2,726 useable surveys from mid and upper-level government managers, found that 39 percent did not know if a program evaluation had been conducted in their agency over the past five years with an additional 18 percent reporting they knew none had been conducted over the same time period. Among those reporting a program evaluation had been conducted over the past five years, more than half (54 percent) reported the evaluation had contributed to program improvement to a great or very great extent. Additionally, almost one half (48 percent) reported significant contributions of the information to the assessment of program effectiveness or value. One of the report's summary findings was that “Agencies' continued lack of evaluations may be the greatest barrier to their informing managers and policy makers and constitutes a lost opportunity to improve the efficiency and effectiveness of limited government resources" (United States Government Accountability Office, 2017, p. 1)."

While performance monitoring has been increasingly relied upon and may utilize empirical indicators, it can only produce trends instead of being able to successfully 
judge effectiveness. Benefits of evaluation research re-emphasize the importance of the evaluation hierarchy, which in practice would blend the concepts of accountability, evidence-based policy, and performance monitoring. The potential problems with conducting a successful evaluation are complicated, as the researcher must learn the balance between how to interact with practitioners and policy-makers while still maintaining the hierarchy and preserving the empirical nature of the evaluation (Mears 2010).

\section{Forensic Criminal Investigation}

Crime scene investigation has developed rapidly over the years and forensic evidence has become an increasingly important piece of these investigations. Historically, three scientific systems were utilized in investigation- anthropometry, dactylography (the study of fingerprints), and deoxyribonucleic acid (DNA) (Swanson, Chamelin, Territo, \& Taylor, 2012). The advent of DNA typing led to a paradigm shift in the discipline of forensic investigation, turning the focus to empirical testing which withstood admissibility standards within the courtroom (Saks \& Koehler, 2005).

Modern forensic criminal investigation focuses on physical evidence recovered from the scene of a crime, with subsequent analysis of this evidence providing a scientific basis on which to build a criminal case that will withstand courtroom scrutiny (Burns, 2007; Hanley, Schmidt, \& Nichols, 2011). Crime scene investigators specialize in the processing of a crime scene and gathering forensic evidence, meaning they should have the ability to recognize, photograph, organize, and collect evidence, ideally being the first to arrive at a secured and untouched scene (Burns, 2007). As of 2011, over 400 law enforcement units existed that were responsible solely for forensic investigation (Larson, 
Vass, \& Wise, 2011). The most recent census of publicly funded forensic labs found there were 351 labs in 2002 while in 2014 this number had increased to 402 (see Durose et al., 2016). This number of labs will probably continue to grow over time.

The overall responsibilities of crime scene investigators include maintaining evidence that is and stays contaminant- free, is fully-documented, and always follows chain of custody (Pepper, 2005). Reliance and cooperation with the Medical Examiner and/or Coroner are also commonplace, as information gained at the scene of the crime could most likely prove beneficial when these medico-legal investigators work to establish the manner of death. This information can provide justification for the classification of the death as natural, homicide, suicide, accident, or undetermined (Haglund, 2001; Snow, 1982). Furthermore, the prevalence of criminal investigation on television shows has had an impact on the knowledge of criminals when committing a crime; though many techniques are fictional, some are represented correctly, allowing criminals to erase trace evidence that could have otherwise been collected (Larson et al., 2011). While standards/techniques in crime scene investigation vary from department to department, the main concerns with the quality of forensic evidence are documentation, collection, and preservation of evidence with additional consideration paid to chain of custody. Standards involving the processes of securing the crime scene and controlling the evidence are illustrated by Swanson et al. (2012), who state the following:

- As rapidly as possible, identify the boundaries of the crime scene and secure it;

- Defining the scene requires officers to make sure they also identify possible or actual lines approach to, and flight from, the scene and protect themselves also;

- Maintaining crime scene control is a crucial element in the preliminary investigation; 
- Separate any potential combatants;

- Set up a physical barrier to protect the scene, prevent contamination or theft of evidence and for your own safety;

- Maintain a crime scene entry log of persons coming to and leaving the scene" (pp. 42-43)

Parts of these guidelines are extremely critical to crime scenes involving forensic evidence. Securing the scene and preventing contamination are of particular importance when protecting the legitimacy of evidence. Documentation is very important at the scene; the initial rough, shorthand record, expands into the crime scene entry log, administrative log, assignment sheets, incidence/offense report, photographic logs, sketches, and evidence recovery logs (Swanson et al., 2012). James and Nordby (2005) described documentation as the most important step in the processing of a scene and placed great emphasis on taking effective notes for a written record to be referred to later. In addition to videotaping and recording the scene, sketches are considered vital, starting with a rough sketch that will later be redrawn and finished; measurements are obtained by identifying two fixed points (either through triangulation, baseline, or polar coordinates) and all measurements are taken in relation to those established points (James \& Nordby, 2005). Every process is considered essential when proving continuity in chain of custody.

With respect to evidence collection, crime scene investigators must do the following: identify each item of evidence they collected and handled, describe the location and condition of the evidence at the time it was collected, state who had contact with and handled the evidence, state when and at what time the evidence was handled, declare under what circumstances and why the evidence was handled, and explain any changes that may have been made to the evidence (Swanson et al., 2012). When collecting evidence, while no rigid order exists for the process, some types of evidence 
should be given priority- for example, evidence that is transient, fragile, or could be easily lost (James \& Norby, 2005). Each piece should be immediately placed in an appropriate primary container and then into a secondary container which must be completely sealed with tamper-resistant tape. Furthermore, each new item should be packaged separately to effectively prevent the chance of cross-contamination. As lesser amounts of evidence are needed due to improvements within forensic analytical techniques, proper collection and packaging of evidence is critical; certain advanced laboratory techniques are rendered impossible if evidence becomes lost or contaminated (James \& Nordby, 2005; Swanson et al., 2012).

As crime scene investigation is highly focused on recovering biological evidence, correct collection and preservation is very important. One primary example of the importance of preservation can be seen with DNA evidence, now considered by many legal entities to be the evidence of choice as supported through case histories (Larson et al., 2011). Because of the significance of DNA, there is a need to protect DNA as it is transported from the field to the laboratory. DNA is subject to degradation immediately following the perimortem period; being a relatively weak molecule, it degrades rapidly in an environment- and time-dependent manner, and is subject to bacteria, fungus, chemicals, ultraviolet light, etc. (Jobling, Hurles, \& Tyler-Smith, 2004; Swanson et al., 2012). When recovered at the crime scene, DNA may be contaminated or destroyed by the inexperienced or improperly trained investigator, either through incorrect collection or preservation methods; this would lead to inadmissibility in the courtroom (Swanson et al., 2012). Therefore, preservation of these types of evidence at the scene becomes paramount to ensure the reliability of subsequent laboratory results. 
Crime scene investigators today also face an ever-increasing problem. The media has significantly affected public perceptions of the criminal justice system. Development and widespread consumption of shows such as CSI, NCIS, Criminal Minds, etc. have perpetuated multiple myths about forensic science, in turn dramatically increasing the expectations of jurors, judges, and attorneys. This has created what is known as the "CSI effect" (Durnal, 2010; Stevens, 2008). One study conducted determined that $26.5 \%$ of participants would not convict a person without some type of scientific evidence (Durnal, 2010). Television series such as CSI have influenced public perceptions such that there is general belief that there is always an ample amount of evidence at a crime scene and the technician just needs to find it, but this is not always the case (Durnal, 2010).

Furthermore, as mentioned previously, the prevalence of criminal investigation on television shows has had an impact on the knowledge of criminals when committing a crime; though many techniques are fictional, some are represented correctly, allowing criminals to erase trace evidence that could have otherwise been collected (Larson et al., 2011).

Regarding the role of forensic evidence in courtroom proceedings, admissibility and quality of evidence is the main concern. A brief overview of the evolution in forensic evidence admissibility points out the importance the investigator is required to place on documentation, collection, and preservation of evidence. A need to evaluate expertise while at the same time being dependent on it creates tension that shapes the way in which courts admit forensic scientific evidence; the ever-increasing role of this evidence in criminal prosecution produced refinement of admissibility requirements (Black, 1988, Giannelli, 1992). Instead of focusing on the evidence presented, when conflicting 
conclusions were provided by medical experts, the qualifications of the experts and the certainty with which their opinion was expressed typically became the subject of discussion instead of the reasoning that connected the facts to the conclusions (Black, 1998).

The "Frye Rule" (Frye v. United States, 1923) became the first effort to standardize admission of forensic evidence and increase objectivity in forensic testimony. The ruling stated that scientific evidence must have general acceptance in the field with which it is associated; however, this test was rarely discussed or analyzed until the establishment of the Federal Rules of Evidence (FRE) (1975) (Black, 1988; Grivas \& Komar, 2008; Wiersema, Love, \& Naul, 2009). Due to inconsistencies in the interpretation of the Frye standard, the Federal Rules of Evidence became the first standardized guidelines regarding forensic evidence and its use in criminal proceedings, intensifying and reevaluating the decisions of Frye (McCormick, 1982; Wiersema et al., 2009). However, as a Common Law rule still applied, inconsistencies existed until the ruling given in Daubert v. Merrell Dow Pharmaceuticals (1993) (Grivas \& Komar, 2008).

Daubert set the standard that testable, replicable, reliable, and scientifically valid methods must be utilized when processing forensic evidence and must provide justification for a specific scientific opinion. The rule was created to prevent court cases from becoming a battle of the experts, keeping a trial decision from being based on the experts as opposed to the evidence (Christensen \& Crowder, 2009; Dirkmaat, Cabo, Ousley, \& Symes, 2008; Wiersema et al., 2009). In addition, Daubert led to the decision that the Federal Rules of Evidence (FRE) superseded Frye and one acceptance rule was 
not enough. Therefore, after the Daubert decision, significant changes were made to the Federal Rules of Evidence, with many new evidence guidelines created. For example, FRE Rule 702 was expanded and emphasized the relationship between data and the methods used to obtain that data rather than the credentials of the expert giving testimony (Dirkmaat et al., 2008). Furthermore, FRE Rule 702 set specific guidelines for satisfying the rule, stating that evidence must be testable by the scientific method, published in a peer-reviewed journal, have established reliability and error rates, and methods or opinions generally accepted within the related scientific community (Wiersama et al., 2009). Daubert with the emphasis on the scientific nature of the processes, placed greater emphasis on the role of investigators at the crime scene and the manner in which the evidence was collected, preserved and analyzed.

Two other cases have been essential for the interpretation of Daubert-General Electric Co. v. Joiner (1997) and Kumho Tire Co. v. Carmichael (1999). In Joiner, it was argued that methodology and conclusions are not completely separate from each other as mentioned in Daubert, and experts must explain how the methodologies have led to their conclusion. In Kumho, the Supreme Court ruled that Daubert's general reliability requirement applied to all expert testimony as opposed to only scientific knowledge. The Court argued that science is too complex to evaluate with only one set of standards and that experts could develop theories based on their observations and experience, applying those theories to the case (Christensen \& Crowder, 2009; Grivas \& Komar, 2008; Saks \& Koehler, 2005). Daubert, Joiner, and Kumho have been established as a "trilogy" that significantly affects the admissibility of expert witness testimony (Grivas \& Komar, 2008). 
Some forensic disciplines can be problematic within the courts due to their reliance on a combination of traditional scientific methodologies and observational methodologies, such as case study evaluations or casework experience (Christensen \& Crowder, 2009). Moreover, due to the variances within the multiple forensic disciplines, the threshold of admissibility may not be equal for some areas, as one may be more sophisticated with more sensitive equipment, have more developed methods, or be able to control for more difficult variables (Christensen \& Crowder, 2009).

One consistency, however, is seen when evaluating admissibility in regard to the "weight" of evidence; that is, its accuracy and believability in terms of procedures followed through the rules of evidence (Hanley et al., 2011). This points to the chain of custody, an essential part of evidence admissibility. Chain of custody specifically applies to any evidence that has been collected and subject to expert analysis; for example, a blood sample or material from a bodily specimen (Hanley et al., 2011). Every person who comes in contact with the evidence must be documented and hold the ability to testify to their handling of the evidence in court; if not, the chain is broken, and the evidence is generally inadmissible (Hanley et al., 2011). By following stringent documentation, collection, and preservation standards, questions regarding chain of custody can readily be answered and preserve the integrity of the evidence.

At present, there exists a disconnect between many of the forensic science disciplines and standards, or a lack thereof, within the criminal justice system. Considering the significance of the forensic sciences to the criminal justice system, it is disconcerting that efforts have not been made to address wide variation in standards and related practices across jurisdictions. Crime scene investigation procedures vary widely 
in best practices, standards, and proper training; this can create multiple difficulties during processing after the evidence is submitted to the lab (NIJ, 2009) as well as in being able to use evidence within the courtroom. Two separate guides released by the NIJ, Crime Scene Investigation: A Guide for Law Enforcement (2013) and Death Investigation: A Guide for the Scene Investigator (2011), are the only current manuals recommended to law enforcement agencies with a forensics unit. And, while highly useful and informative, when the content is analyzed, it is evident that one guide is for law enforcement and the other for civilian investigators. Typically, the training and education levels of these separate groups are disparate, and the abilities of individuals within the unit may vary extensively.

Death Investigation (NIJ, 2011) includes specific information regarding chain of custody, laws related to the collection of evidence, descriptive documentation, explicit entry and exit procedures, familial notification procedures, and evaluation of the decedent. Conversely, Crime Scene Investigation (NIJ, 2013) places more emphasis on arriving at the scene and prioritizing efforts, securing the scene, identification of boundaries, and documentation of those surrounding the scene. One may argue that this difference of emphasis is correct procedure. Death investigators and the law enforcement officers play different roles with challenges dependent on which unit is the first to arrive at the scene, size of an agency and resources sufficient to employ both criminal and crime scene investigators and who is specifically responsible for documenting, collecting, and preserving the evidence differentiates these roles. However, it would seem more useful to ensure that everyone who may come into contact with a crime scene at any point in time is properly trained and educated, in addition to being informed of all duties in 
relation to a forensic field investigation and so to consolidate the investigative guidelines for delivery to both law enforcement personnel and civilian investigative personnel.

\section{National Institute of Justice Report}

Faced with an ever-growing need to address forensic investigation, the National Institute of Justice (NIJ) commissioned a committee to chart an agenda for progress within the forensic science community and related disciplines. One main goal was to "disseminate best practices and guidelines concerning the collection and analysis of forensic evidence to help ensure quality and consistency in the use of forensic technologies and techniques to solve crimes, investigate deaths, and protect the public" (NIJ, 2009, p. 2). Varied issues related to the improvement of forensic science were explored, including challenges facing the forensic science community; disparities within the community; the lack of mandatory standardization, certification, and accreditation; the broad range of forensic science disciplines; admission of forensic science evidence in litigation; and the political realities facing the forensic science community as a whole.

In recent years, research into the forensic disciplines has been highly

underfunded, and therefore limited opportunities existed for research (NIJ, 2009).

Additionally, the forensic community as a whole is pieced together with multiple types of practitioners who hold varying levels of education and experience, leading to a disconnect between professional culture and standards; moreover, in order to conduct research, forensic academics and practitioners must collaborate with the police, a situation which often results in miscommunication, misunderstanding, and misguided efforts (NIJ, 2009). Though forensic practices were developed and created primarily through criminal justice law enforcement agencies, evidentiary standards and chain of 
custody were tailored around the courtroom instead of applied science. Previous examination has suggested that testimony regarding forensic investigation and evidence is entering risky territory, as research is scant and not systemic (NIJ, 2009). And, while Daubert continues to be the standard in most US jurisdictions, forensic evidence that does not meet the specified requirements will be less than useful.

With this in mind, recommendations within the NIJ (2009) report emphasize increased standards in most forensic fields related to reporting and testifying in relation to evidence and field investigations must be increased. To meet these standards, increased educational and training requirements are necessary. The report states that the "established scientific knowledge, principles, and practices of the field are best learned through formal education and training and the proper conduct of research (p. 217)." Therefore, the NIJ (2009) recommended that units must move away from on-the-job training towards higher education that is scientifically sound and encompasses all aspects of forensic investigation. Additionally, those in the field need continuously updated training due to the nature of forensic science as a discipline, as it is still in rapid development and new techniques are created as old ones are refined on a continuous basis. The NIJ (2009) provided a recommendation of core elements that should be part of that training, and these included standards of conduct, safety, policy, legal aspects, evidence handling, and communication. Development of training programs that follow these criteria must be a primary goal for agencies to produce quality forensic evidence that meet current legal standards. 


\section{Prior Research on Crime Scene Investigators}

The following two studies, conducted outside the United States, are relevant to the current research and add to the prior discussion. According to Kelty, Julian, and Robertson (2011), previous literature has identified effective crime scene processing as reliant on scene control/security and the easy exchange of information between crime scene investigators and detectives; however, the authors maintain that this neglects the aspect of human involvement in the processing, meaning the communication and thought processes of each individual member.

From this, Kelty et al. (2011) attempted to identify qualities and attributes of "high-performing" crime scene examiners through focus groups and one-on-one interviews with 74 senior police. officers, civilian police staff, forensic scientists, and a group of peer-identified "high-performing" crime scene examiners from major crime divisions, all drawn from five Australian police jurisdictions. "High-performing" crime scene examiners were identified through a multi-step process. Essentially, these individuals were viewed by management and peers to have high suspect identification rates, positive annual performance reviews, positive impact on investigations (e.g., good scene management, collects high quality samples, etc.), and to be highly knowledgeable in crime scene management, sample recognition, recording, and recovery.

Results provided a set of critical skills, identified across all positions and jurisdictions. These skills were then amalgamated into seven performance indicators: cognitive abilities, knowledge base, experience, work orientation, communication skills, professional demeanor, and approach to life. Cognitive abilities included being open to new ideas and alternative methods, objective decision-making, and high-level 
multitasking, planning, and consequential thinking abilities. Knowledge base consisted of a University degree, knowledge of legalities, police culture, and police investigation, and sound knowledge of scientific principles. Experience included real-life experience at crime scenes, in the courtroom, highly charged situations, age, and maturity. Work orientation involved good time management, genuine interest and dedication to the role, and self-motivated learning that was results-driven.

Communication skills were identified as active listeners with good negotiation and interpersonal skills, inclusive and team-oriented, and high-level written and verbal skills. Professional demeanor included unassuming, modest, respected, high-credibility, defends decisions, self-confident in abilities, non-judgmental, and not easily influenced by external factors or people. Finally, approach to life involved fitness and health orientation, positive worldview, realistic about life events, "black" sense of humor, consistent and resilient, creative, innovative, clear life/work separation, and strong social/family support.

In addition, Kelty et al. (2011) presented five effects that "high-performing" crime scene examiners had on their work, as reported by their peers. The "high performing" crime scene examiners, as reported by their peers, collected higher quality evidence, took more responsibility on scenes where their colleagues were not as experienced, had a large impact on resource allocation in the first stages of an investigation, reduced resource use and staff time in the lab by only submitting valid samples, and took more time processing and "connecting the dots" at a crime scene. Ludwig, Edgar, and Maguire (2014) presented a model of performance management that sought to utilize activity measures and review processes to provide 
insight into the effectiveness of crime scene examiners. This model was based on the evaluation measures of Durham Constabulary in the United Kingdom, an agency that served more than 600,000 individuals and responded to approximately 23,000 crimes per year. Twenty-four crime scene examiners within the Scientific Support Unit responded to scenes through a deployment model to ensure they were not restricted from certain jurisdictions.

Performance measures for each individual were recorded on a monthly basis and then reviewed quarterly to determine if they were in line with established targets and averages, these targets being identified as scene attendance, forensic conversion rates, and quality of evidence. Scene attendance involved both operational and non-operational tasks in comparison with days worked, which then allowed for an average per day of tasks completed. Forensic conversion rates were defined as the percentage of evidentiary samples that resulted in the identification of an individual and controlled for the amount of scenes attended by each individual. Finally, quality of evidence was determined through the quality of fingerprint lifts collected, meaning how many of those fingerprint lifts could be successfully compared to attempt an identification.

By presenting this model, Ludwig et al. (2014) intended to show a method of managing overall productivity that could be easily implemented in other jurisdictions. However, it was also argued that the overall performance of crime scene examiners required an even more comprehensive assessment of activity and productivity; for example, adding the conversion rate of identifications into detections and other outcomes. Overall, the authors concluded that performance indicators can be extremely useful in overall management but must reflect measures of meaningful and appropriate activities. 
Though no research on team performance has been conducted on crime scene units, prior research on team performance also informed the current program evaluation. As defined by Koslowski and Bell (2003, p. 334), work teams are

“...collectives who exist to perform organizationally relevant tasks, share one or more common goals, interact socially, exhibit task interdependencies, maintain and manage boundaries, and are embedded in an organizational context that sets boundaries, constrains the team, and influences exchanges with other units in the broader entity."

Program evaluations are concerned with what influences outcomes of an organization/agency/unit/program. Individual team member characteristics such as competencies, personalities have been repeatedly identified as contributing to team performance (McGrath, 1964; Cohen and Bailey, 1997; Marks et al., 2001; Mathieu et al., 2006). These have additionally been labeled as "mediators" of team performance and constitute "emergent states" (e.g., potency, psychological safety, and collective affect) (Mathieu et al., 2006). Organizational culture is a set of shared assumptions that guide what happens in organizations by defining appropriate behavior for various situations (Ravasi \& Schultz, 2006). Subunits within the organization and their members may develop comparable assumptions concerning appropriate behaviors for various situations. These characteristics of the "culture" of the team have also been referred to as "performance behaviors" as distinguished from "performance outcomes". That is, they are actions relevant to team performance and goal attainment (Beal et al., 2003). Other characteristics of team members and team "culture" focus on the extent to which members of teams possess the necessary skills and competencies to perform team tasks (Welbourne et al., 1998). 


\section{Comparative National Sample}

Lastly, Rausch's (2015) prior study provided empirical data that related to the issues raised in previous scholarly literature. The concept of interdisciplinary incorporation and the multitude of recommendations contained in the NIJ (2009) study created the basis for the analysis. Sample agencies were drawn from the National Directory of Law Enforcement Administrators (45th ed.), and included municipal, county, state, and federal agencies, with a final sample total of 117 respondents. Within these agencies, 87 served a population of 250,000 or more, and most agencies within the sample served populations containing 500,000 to 750,000 residents. The vast majority of the survey was directed at the 86 respondents who indicated their department maintained a specialized forensics unit.

Results reflected multiple inadequacies within the current structure and processes of criminal investigation units. Standard operating procedures were not present in $24.7 \%$ of the units. Copies of unit standards provided by respondents indicated wide variation and a lack of consistency across agencies. The majority of units surveyed had as a minimum education requirement a high school degree $(57.0 \%)$ though they did report a preference for hiring unit members who had an undergraduate degree (52.9\%).

Training, prior to entering the field, was provided by slightly more than one out of four $(26.5 \%)$ agencies, with many units having no yearly training requirement $(40.5 \%)$. Among those units that did require training, 51.0\% stated it was the same as the original department training provided, and $60.6 \%$ of those who did not require yearly training had no requirement for routine training whatsoever. In addition, while $99.0 \%$ of units encouraged members to attend outside training, it was only required by $24.7 \%$. And, in 
spite of the lack of requirements for training, virtually all agencies reported the availability of department funding $(90.2 \%)$ to support outside training.

Furthermore, training administered lacked comprehensiveness in terms of the interdisciplinary nature of forensics. While most units had at least one member who had completed training in bloodstain pattern analysis $(87.1 \%)$, DNA recovery $(84.7 \%)$, and trace evidence collection (83.5\%), only $35.3 \%$ had at least one unit member trained in forensic entomology and $25.9 \%$ in forensic anthropology. Finally, only $8.1 \%$ of the units required any kind of national certification within the forensic disciplines though $31.7 \%$ of respondents indicated they did encourage national certification. While publicly funded crime laboratories are not the same as forensic crime units within police agencies, the Bureau of Justice Statistics has conducted a census of these laboratories. The most recent findings were published in 2016 and suggest that not only are there increasing numbers of forensic labs but that more of these labs are certified by the American Society of Crime Lab Directors/Laboratory Accreditation Board. Additionally, virtually all laboratories (98\%) conducted proficiency training, maintained a code of ethics (94\%), and employed at least one certified analyst (72\%). Forensic capabilities have clearly increased nationally over the past 10 years. The resources and services provided have moved more generally to adhere to the NIJ (2009) recommendations. The current research addresses the NIJ standards within forensic crime units located within police agencies. These forensic crime units differ from crime laboratories in that the personnel conduct investigations and evidence collection as well as some limited analysis. In contrast, laboratories primarily conduct analysis and only on a limited bases are involved in crime scene evidence collection. The purpose, goals, and objectives of the current study are 
firmly rooted and directed generally by available research and, particularly, the NIJ (2009) study and its recommendations. Rausch's (2015) results indicated significant issues currently facing forensics units and allows for measurement of KPD's unit against the only baseline currently available.

\section{History of KPD and the Forensics Unit}

In 1815 , the City of Knoxville was incorporated and received its first city charter from the Tennessee General Assembly, with a mayor and board of alderman being elected shortly thereafter. Together this group elected a town constable who was solely responsible for policing the city. In 1849, the town constable was instructed to "summon" four responsible citizens to assist in patrolling the streets from 10:00 PM until daylight, though the "assistant watchmen" were not paid for their services. This continued on until 1857 , when the first chief of police was named, and in 1859 a second chief and two new assistants joined in. More and more continued to be employed by the police force by 1885, a properly organized police department had formed, guided by the mayor, the alderman, and a three-member board of public works. The department has since undergone many changes over the last century to become what it is today and was accredited in the late 1980's (Lynch, Webb, \& Ferguson, 2001).

Formed in the fall of 1975, the Knoxville Police Department Crime Scene Unit originally was called the Criminalistics Unit. However, confusion over the purpose of this unit among the public resulted in it being renamed the Crime Lab. At its formation, there were five members - one Lieutenant, one Detective, and three Officers. The unit operated with limited resources - one camera, one fingerprint kit, and a Dodge van.

Evidence was collected and processed in the office occupied by the unit. Many times, the 
unit members would respond to scenes alone, and they were responsible for working scenes ranging from homicides to car break-ins ${ }^{1}$.

From around 1975 until the early 1980's, organizational politics in the department determined an officer's ability to join the Crime Lab. In addition, officers who did not fit anywhere else in the department were assigned to this unit. New members received onthe-job-training from senior members of the unit. Until 1981/1982, all members of the unit were sworn officers. In late 1981/early 1982, civilian technicians were integrated into the unit. The integration was, however, not consistently successful and turnover among civilian personnel was quite high for approximately ten years. During the late 1980's, once KPD became an accredited police department, the unit became known as the Crime Scene Unit and began to shift to the current unit and its operations. The unit is currently called the Forensics Unit (Lynch et al., 2001).

\footnotetext{
${ }^{1}$ History of the crime scene unit was relayed by Art Bohanan, who served on the unit beginning with the inception of the unit (personal communication, June 2018).
} 


\section{CHAPTER III}

\section{PROGRAM EVALUATION RESEARCH QUESTIONS}

As noted previously, the formative program evaluation sought to identify the effectiveness of the KPD crime scene unit and what characteristics, processes, etc. might be related to unit effectiveness or a lack thereof. Information contained in the NIJ (2009) report as well as the studies by Kelty et al. (2011), Ludwig et al. (2014) and Rausch (2015) were used to formulate and operationalize the evaluation questions. Research consisted of four phases:

1) Perception of the effectiveness and efficiency of the unit among KPD patrol operations personnel.

2) Assessment of the extent to which the policies and practices of the KPD forensics unit met standard set forth in the NIJ (2009) Report on forensic science.

3) Assessment of the culture and interpersonal relations between members of the unit that could potentially affect unit operations.

4) The extent to which the findings of the current case analysis of KPD compare to characteristics of a national sample of forensics units.

Data collection involved a mixed-methods approach and included surveys, interviews, review of policies and procedures, and univariate analysis was conducted.

\section{User Perceptions}

The first phase of the program evaluation was an examination of perceptions of the crime scene unit among sworn personnel in the agency. It focused on how members 
of the organization (KPD) view the unit and its value, performance, and contribution to the organization. The premise for this question was that if personnel (users) in the organization did not view the unit as effective, it would not be used as readily or with confidence in the unit's services.

\section{Standards, Best Practices, Education and Training}

The second phase of the program evaluation sought to assess the extent to which the crime scene unit met recommendations of the NIJ report on forensic science (2009). Specifically, two areas of recommendation were emphasized: Best Practices and Standards and Education and Training.

Best practices and standards. The NIJ Report recommendation for Best Practices and Standards in forensic sciences states that "although there have been notable efforts to achieve standardization and develop best practices in some forensic science disciplines and the medical examiner system, most disciplines still lack best practices of any coherent structure for the enforcement of operating standards, certification, and accreditation (...). In short, oversight and enforcement of operating standards (...) are lacking in most local and state jurisdictions (NIJ, 2009, p. 23)." With this in mind, specific research questions were formulated, and included the following:

- $\underline{\text { Standards }}$

1. Were there written standards for field investigations in the unit?

2. Did the standards cover all relevant practices related to evidence extraction, preservation, documentation and presentation?

3. What served as the basis for the standards?

4. Were these standards routinely updated?

5. Were these standards routinely disseminated? 
Education and training. In regard to education and training, the NIJ

recommendations stated that

"forensic science examiners need to understand the principles, practices, and context of scientific methodology, as well as the distinctive features of their specialty. Ideally, training should move beyond transmittal of practices to education based on scientifically valid principles. In addition to the practical experience and learning acquired during an internship, a trainee should acquire rigorous interdisciplinary education and training in the scientific areas that constitute the basis for the particular forensic discipline and instruction on how to document and report the analysis" (NIJ, 2009, pp. 26-27)."

Specific questions were developed from these recommendations and included the following:

- Education

1. What were the education levels of unit members?

2. For those with degrees, what was their subject area?

- Training

1. What training was required before an individual was allowed to participate in field investigations?

2. In what areas of traditional or nontraditional field methods have unit members been trained?

3. What routine training was administered?

4. Was yearly training required?

5. Does the training include interdisciplinary methods?

6. Was training with an outside agency required?

7. What was the level of knowledge of traditional vs. interdisciplinary methods among unit members?

Data collected to answer these research questions came from two sources. First, organizational policies and procedures for the crime scene unit were reviewed for consistency with the standards and second, surveys of and interviews with crime scene 
unit personnel were used to collect information on their educational and experiential qualifications and the consistency of these credentials with departmental standards.

\section{Unit Culture}

The culture within an organization and/or unit of an organization has an effect on the performance of the unit within the organization. Questions informed by the research on team performance and various characteristics, beliefs, competencies and relationships among members of the team that would be reflective of the culture of the unit and therefore had the potential to affect unit performance were contained in the survey. These included the following:

- Unit Culture

1. How does rank influence level of involvement at the scene?

2. How do civilian responsibilities differ from officer responsibilities in terms of unit functions?

3. What is the nature of the interactions between officers and civilians?

4. Are members of the unit engaged with one another?

5. Was there encouragement and good rapport between unit members?

\section{Comparative Performance Nationally}

Lastly, the descriptive information from the current case study was compared, where applicable, to the baseline data on crime scene units established by Rausch (2015). This provided a means of determining how the current unit under review compared to aggregate data on comparable units within the national sample. First, the findings from KPD were compared with the entire sample. Then the KPD results were compared to agencies within the national sample that were similar in size and jurisdiction were compared to KPD. The goal was to see how KPD compared to other forensics units in terms of standards, education and training, and unit resources. 


\section{CHAPTER IV METHODOLOGY}

The agency under consideration, the Knoxville Police Department, was a convenience "sample". Access to the department and willingness of the department to support the research was gained through connections to command staff within the department. However, once access was provided, command staff remained neutral during the research process and all participants were protected via consent forms that protected their anonymity and additionally stipulated their participation was voluntary. In addition, several organizational "layers" were present between the agency commander and the forensics unit.

A mixed methods approach was used to collect information to answer the various research questions that constituted the program evaluation. As noted previously, four methods were used to gather data. These methods included: surveys, interviews, policy and procedure review, and comparison on selected characteristics to a national sample of forensics units.

\section{User Perception: User Survey}

In order to determine user perceptions of the crime scene unit, all members of the department involved with patrol operations (378) were sent a link to an online survey (Survey Monkey) via email. The survey contained questions pertaining to awareness of the forensics unit and the services provided, utilization of these services by the 
respondent (including how often and what types of services), what services respondents would prefer to have performed by the unit, timeliness of the unit, thoroughness of the unit, relationships between unit members and investigators/patrol, perspectives on the training of the forensics unit, opinions on the staffing of the unit, and contribution of the unit to case conversion rates. The email asked the potential respondents to please take the time to complete the survey, informed them that their participation was voluntary, and their responses would remain anonymous and confidential. A total of 51 surveys (13\%) were returned in useable form.

Unfortunately, demographic information on the respondents was not collected. Additionally, the response rate, $13 \%$, was low. While these are two significant limitations of the survey, it is not necessary to totally discount the findings. Recognizing the limitations and noting the formative nature of this evaluation, the findings are included in the current research. The survey questions utilized in this portion of the study are located in Appendix A.

\section{Forensics Unit Personnel Survey and Interviews}

Information on unit culture and the extent to which unit policies met "best practices" for standards, education, and training was collected through the administration of surveys and follow-up interviews with unit personnel. The sample for this portion of the research included all investigators from the crime scene unit of KPD, civilian and sworn. Some civilian staff from the unit were not included in the sample because they did not participate in field investigations. If a unit member did not feel comfortable participating in the research, for any reason, they were exempted from participation. Participants had the option to participate in only the survey, only the interview, both the survey and 
interview or not to participate at all. All unit members, who chose to participate, provided consent through a formal "Use of Human Subjects Consent Form" which was signed twice - once before they participated in the survey and again before participating in an interview. Following the provision of informed consent, a survey was distributed to all members included in the sample of crime scene unit personnel. Seven out of nine members agreed to participate for a response rate of 78 percent. A copy of the consent form is located in Appendix B.

This survey contained questions pertaining to basic demographic information on the members of the unit (age, gender, civilian/sworn, rank/position), time in forensic-related work, time in their current position, former forensic jobs, education levels and subject area, training they have received, and national certifications held. Both open-ended and closed-ended Likert-type scale questions were used to gather the information. The survey instrument used in this portion of the study are located in Appendix C.

The respondents were fairly evenly distributed in age with approximately half being under 44 years of age (57\%) and half being over 55 years of age $43 \%$ ). Similarly, approximately one half of the respondents were female $(43 \%)$ and one half were male (57\%). Civilian and sworn members were also relatively evenly represented among the respondents, at $57 \%$ and $43 \%$ respectively. Agency ranks represented within the unit included three Evidence Technicians, one Crime Scene Technician I, one Officer, one Sergeant, and one Lieutenant.

Following administration of the survey, unit personnel were selected for one-onone semi-structured interviews. As noted previously, participants were asked to sign their consent form twice to ensure informed consent for both data collection procedures. 
Interview questions were an extension of those contained in the unit personnel survey and pertained to: individual perspectives on appropriate educational requirements, ideas on interdisciplinary and traditional field methods, opinions on interdisciplinary incorporation and the creation of uniform standards of investigation in the field, their personal responsibilities in regards to a forensic investigation, and their interpretation of the "culture" (social, professional, personal) of the unit as a whole. The design for the interview guide is located in Appendix D.

Interviews were conducted between November $14^{\text {th }}, 2017$ and January $10^{\text {th }}, 2018$. These interviews took place at both the Knoxville Police Department Headquarters and the Knoxville Police Department Forensics Investigation building. Out of the nine individuals in the unit, seven agreed to be interviewed. Interviews consisted of five questions and ranged from five to 25 minutes in length. All interviews were recorded using an Olympus WS-853 8GB Digital Voice Recorder. Once the interviews were completed, they were de-identified and fully transcribed.

Qualitative data from interviews and open-ended survey questions was analyzed using content analysis. Content analysis is considered both a quantitative and a qualitative research method. According to Kort-Butler (2016), quantitative content analysis looks to recognize patterns across the observed content and therefore create categories in which the content can be analyzed. Coding is developed by utilizing research or theoretical literature to define units in which words, phrases, images, or overall themes of the content will be placed; categories are then defined, either narrowly or broadly, and may or may not be exclusive. The content is then coded appropriately. Analysis of the data is driven by the existing research questions, and the coded content is 
quantified by creating variables that are meaningful in regard to the questions the researcher is attempting to answer.

Qualitative content analysis, also known as ethnographic content analysis, works much as the same as quantitative content analysis, but emphasis is placed on descriptive and conceptual data. Review of the literature should guide the selection of the problem to be examined, and once a medium is chosen the researcher should also consider the production process and context of that medium. Theoretically derived concepts then guide the development of a protocol with preset coding categories, though these categories are more open-minded than in quantitative content analysis. Throughout data collection, these categories may be modified, or new categories may be created. Analysis of the data seeks to explore, describe, explain, and potentially theoretically link separate elements of the data (Kort-Butler, 2016).

The interview data was transcribed and then coded using theme/pattern identification. Once the main themes/patterns were identified, responses were recoded to identify subcategories and other pertinent information. Informed by prior research on team performance, results from both the survey and the interviews were organized into formative categories addressing perceptions of unit culture including cohesiveness, training confidence, relations between unit personnel, training and education expectations, necessity of certification, and interdisciplinary education/training.

\section{Policy and Procedure Analysis and Comparison with Data from a National Sample}

Analysis of the consistency of KPD policies and procedures included a review of written policies and procedures in addition to the information gathered from current personnel through interviews and surveys. Policies and procedures used for analysis 
included both the specific written policies and procedures of the agency but additionally the more general Commission on Accreditation for Law Enforcement Agencies (CALEA) standards because the KPD is a CALEA certified agency.

Data comparison was made with the results from Rausch's (2015) study. In that study, the sample was drawn from the National Directory of Law Enforcement Administrators $\left(45^{\text {th }}\right.$ ed.). Only agencies serving a population of 250,000 or more were chosen for the sample, with the exception being states that do not have this population density in municipal or county jurisdictions. In those cases, the top three populated cities/jurisdictions were selected. Surveys were mailed on January $23^{\text {rd }}, 2014$, with respondents requested to return the survey by March $1^{\text {st }}, 2014$. Identifying data was collected but reserved for classification purposes only to protect the anonymity of the agency. The survey instrument included 16 questions addressing standards, training, education, and certifications of an agency's forensics unit. 


\section{CHAPTER V}

\section{RESULTS}

\section{Knoxville Police Department Forensics Unit}

The Forensics Unit is part of the Criminal Investigations Division of the

Knoxville Police Department. The mission statement of this division is for the Pursuit of

Excellence in Interaction of the Police with the Community and states:

We are committed to a police-community partnership in providing the delivery of police services. We shall accept a leadership role in increasing community understanding of our abilities and limitations. Proactive policing and crime prevention shall be our primary focus (Knoxville Police Department, 2017)

The Forensics Unit consists of six details: Crime Scene Processing, Fingerprint Identification, Firearms Identification, Photo Lab, Phone Forensics and Polygraph. The unit is staffed by sworn and civilian personnel. The members of the Forensics Unit are graduates of the University of Tennessee's National Forensic Academy located in Oak Ridge, Tennessee. Training is also provided through cooperative local, regional and national agreements. The unit provides a wide range of services "from bullet comparisons to crime scene reconstruction” (Knoxville Police Department, 2017, p. 29).

The Forensics Unit responded to more than 3,764 calls for service in 2017, ranging from vandalism to homicide. The unit gathers evidence from crime scenes such as: blood spatter pattern documentation, latent fingerprints, DNA trace evidence, bullets, shell casings, shoe impressions, chemically developed bloody handprints, impression 
casting of footprints, tool marks and fingerprints from weapons used in crimes to aid in solving violent and other crimes in Knoxville. In 2016, the Forensics Unit responded to more than 3,718 calls for service, and in 2015 , they responded to more than 4,262 calls for service.

Multiple forensic services are provided by the Crime Scene Detail and include latent fingerprint identification, blood spatter analysis, firearms reconstruction, firearms bullet and shell casing matching, and processing and preservation of evidence collected at crime scenes. Crime scenes may also be documented with photography, videotaping, field sketches and laser data plotting. The Crime Scene Unit provides services that support field officers, investigator and court prosecutors. The Polygraph Detail conducts criminal and pre-employment polygraph tests and assists investigators in identifying perpetrators and bringing cases to successful closure. In 2017, the detail administered 155 polygraph examinations (Knoxville Police Department, 2017). The Polygraph Detail is also responsible for the development of suspect composites (sketches) used in crime bulletins to identify crime suspects.

Photographic evidence also plays a strong role in the criminal prosecution. In 2017 , over 66,000 photographs were taken of crime scenes or department events and 16,243 images were processed by this unit (KPD, Annual Report 2017). The Firearms Detail is participating in the Bureau of Alcohol, Tobacco, and Firearm's (ATF) National Integrated Ballistic Information Network (NIBIN) program. The unit has a BRASSTRAX system that captures "high-resolution 2D images and precise 3D topographic information of significant regions of interest which is then submitted to the NIBIN database" (KPD Annual Report 2017). The firearm evidence is imaged and then 
searching a national database for potential matches. The positive matches are confirmed with the use of a comparison microscope. In 2017, over 403 microscopic comparisons were performed resulting in 41 positive matches (KPD Annual Report 2017). The Firearms Detail also assists other agencies (local, state, federal) with firearms related investigative issues and shares resources such as the test firing tank and indoor range. The Firearms Unit added two additional firearm examiners in 2017.

The Fingerprint Detail uses the nationwide computerized Automated Fingerprint Identification System (AFIS) to assist officers and investigators in matching fingerprints to unidentified suspects and victims. The detail searches for evidence left behind by suspects at every crime scene. Collected latent prints are then hand-entered into AFIS. The detail is responsible for matching the latent print to the identified suspect. The Fingerprint Detail is regularly contacted by other agencies to assist in the identification of victims and suspects in homicides and burglaries. In 2017, this detail conducted more than 746 searches with 239 AFIS identifications made (KPD Annual Report 2017)².

\section{User Perceptions of the Knoxville Police Department Forensics Unit}

A user perception survey was sent to all (378) members of the Knoxville Police Department. The solicitation produced 51 completed and useable surveys, a response rate of 13 percent. While the response rate is low and therefore, the results may be less definitive, the results of this survey suggest certain trends reflecting perceptions of the Forensics Unit by patrol operations personnel. As shown in Chart 1, all of the respondents $(100 \%)$ were aware the department had a dedicated forensics unit. When asked if they were aware of the services provided by the Forensics Unit, all (100\%) of the

\footnotetext{
${ }^{2}$ The purpose of the Fingerprint Detail and Photography Lab is to assist in investigations without having to rely on outside processing.
} 


\section{Chart 1}

KPD Awareness of Forensics Unit Services

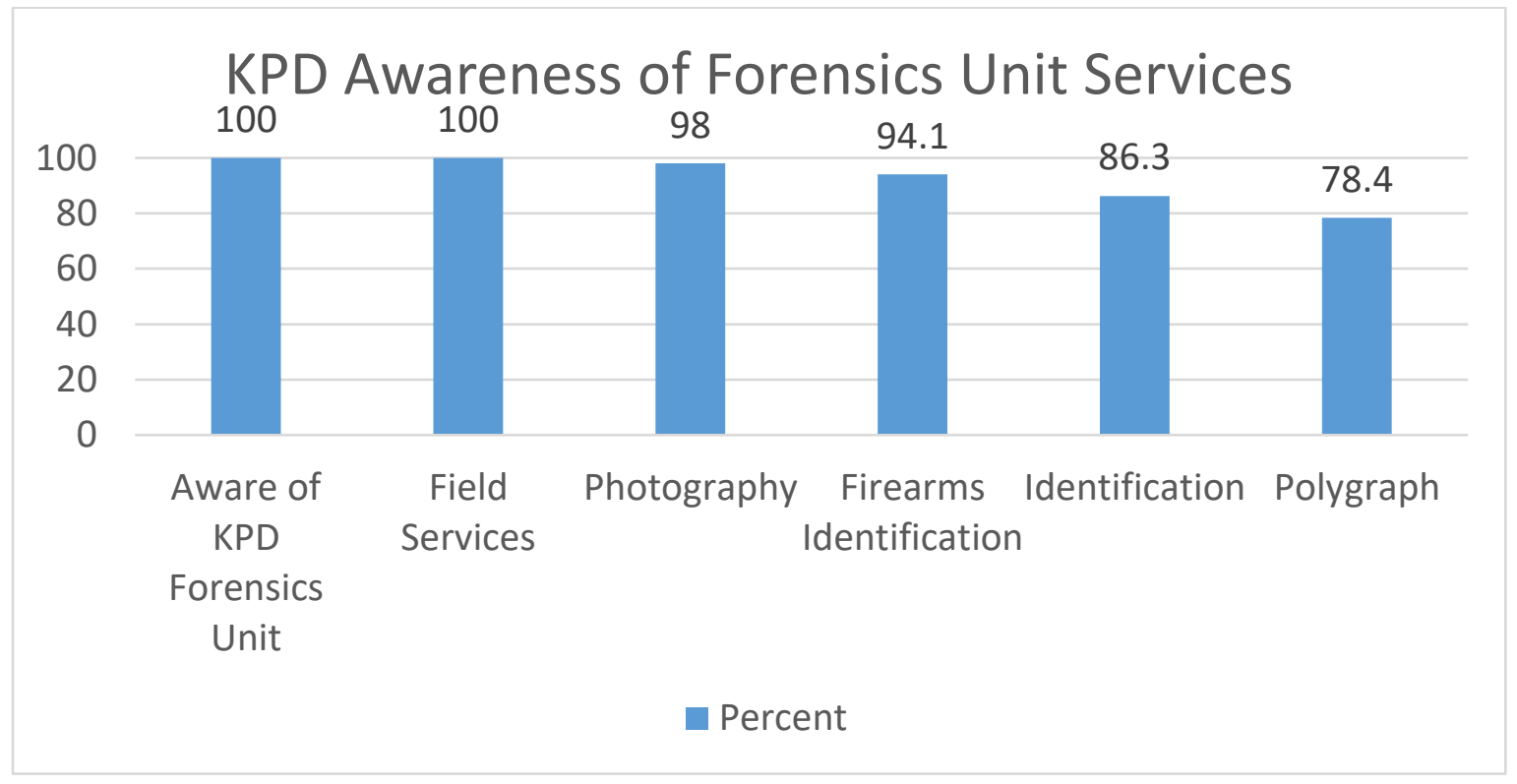

respondents were aware of Field Services (including collecting/processing/submitting evidence and photograph at the scene). A significant majority were also aware of the Firearms Identification Detail (94.1\%), the Identification Detail (86.3\%), the Photography Lab (98\%), and the Polygraph Detail (78.4\%).

A majority of the respondents (96.1\%) had utilized the services provided by the Forensics Unit at some point in time. Those respondents who had used the unit were additionally asked how often they had used the unit over the past year. The average number of times respondents had used the forensics unit was 31-40 times, with a median of 20 times. Approximately one-third of respondents (34\%) had utilized the unit between 1 and 10 times, with another $17 \%$ being the "most frequent users" reporting use $100+$ times over the past year. 


\section{Chart 2}

KPD Forensics Unit Services Utilized in the Past Year

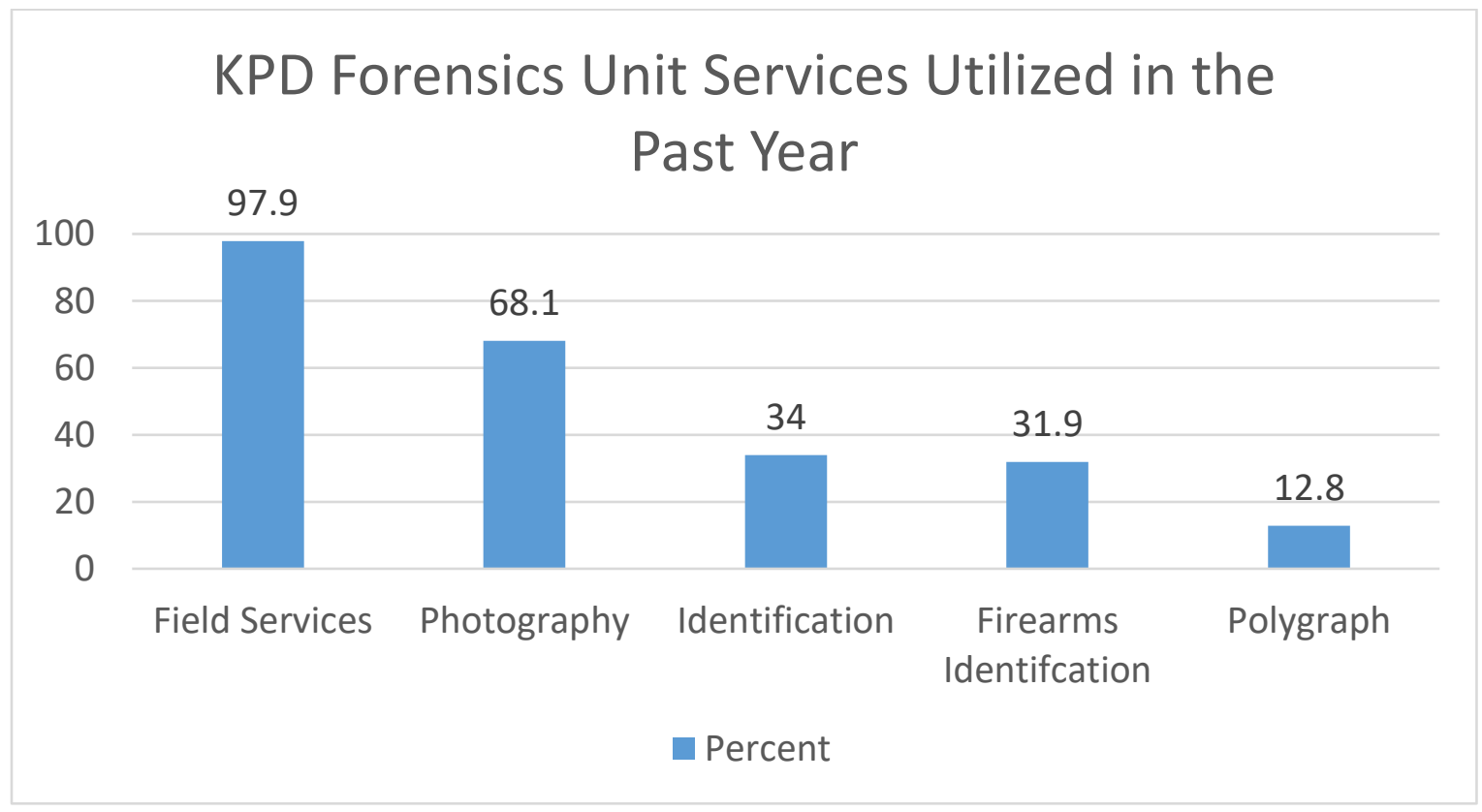

Chart 2 contains findings on which forensics unit services respondents had utilized. As shown in this chart, respondents were most likely to have used Field Services $(97.9 \%)$ followed in frequency of use by the Photography Lab $(68.1 \%)$, Identification Detail (34.0\%), Firearms Identification Detail (31.9\%) and Photography $\operatorname{Lab}(12.8 \%)$.

When asked what forensic-related service the respondent would prefer to have provided by the Forensics Unit, most respondents (58.8\%) did not provide an answer; 11 wrote in this response, and 10 skipped the question. Out of the 30 respondents who answered this question, $17.1 \%$ percent responded that the current services were satisfactory, $14.6 \%$ responded that they would like to have fingerprint identification done in-house, $9.8 \%$ responded that they would like 


\section{Chart 3}

\section{KPD Opinions of the Forensics Unit}

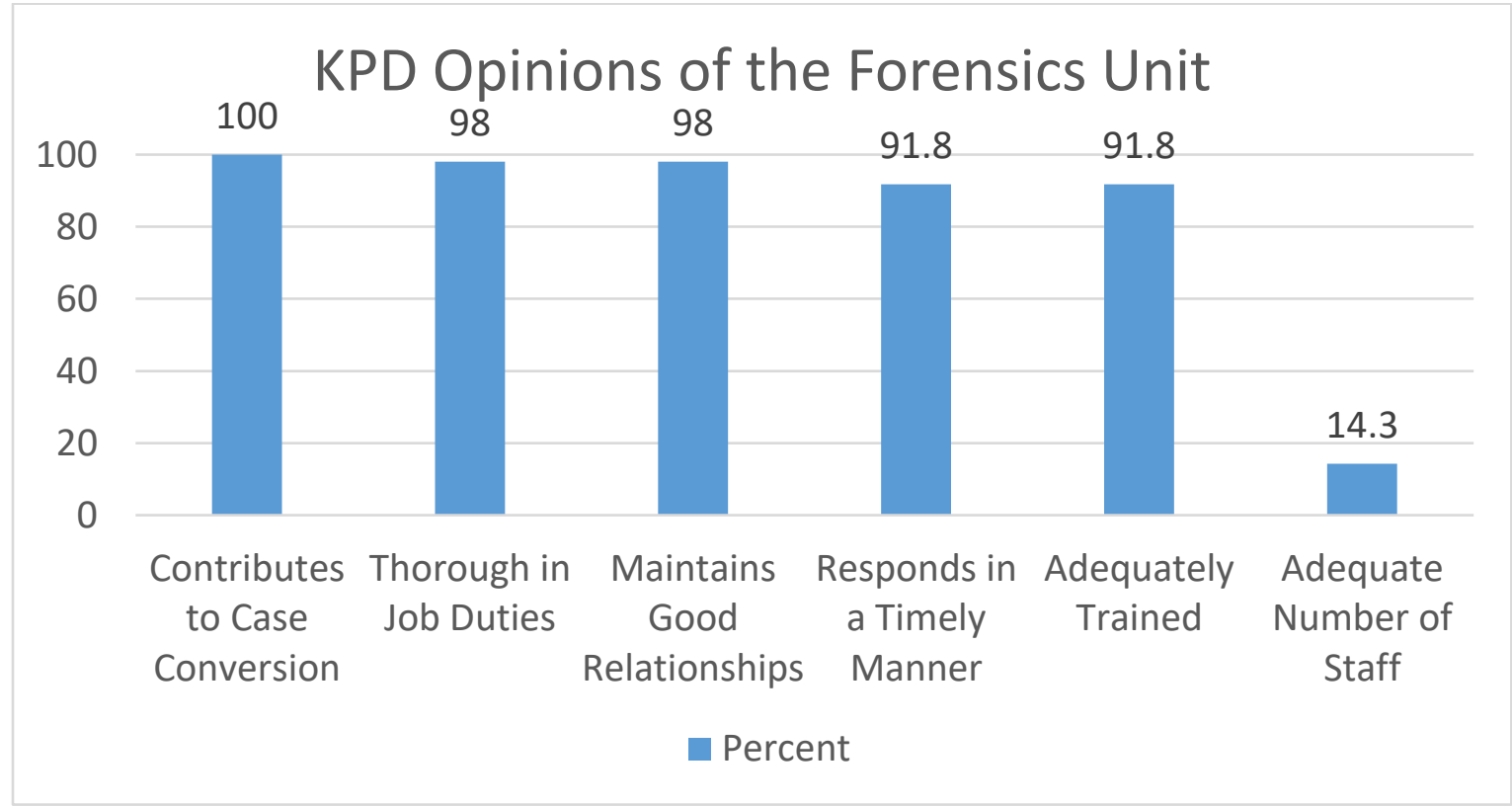

to have 24 -hour coverage from the unit, and $7.3 \%$ stated they would like to have identification and toxicology services done in-house ${ }^{3}$.

The last six questions focused on the respondent's opinion of the Forensics Unit. Responses to these questions are summarized in Chart 3. A majority (100\%) believed the unit contributed to case conversion. Another majority believed the unit was thorough in the performance of its job duties (98.0\%) and maintained good relationships with investigators and patrol $(98.0 \%)$. Another majority $(91.8 \%)$ additionally believed members of the Crime Scene Unit were adequately trained, responded in a timely manner (91.8\%). However, only $14.3 \%$ reported the unit had sufficient staff.

\footnotetext{
${ }^{3}$ The unit is not physically staffed $24 / 7$. Instead the unit has one or two individuals who are "on call" overnight.
} 
The findings of the unit personnel survey suggest that the unit and the services it provides were well-known by those members of patrol operations within the department who responded to the survey. The unit and unit services are frequently used by patrol operations personnel and are highly regarded. The most significant suggest made in terms of improving the unit was to expand staffing to provide more complete services $24 / 7$.

\section{Best Practices and Standards}

As noted in a prior section, the NIJ Report recommendation for Best Practices and Standards in forensic sciences states that even though attempts have been made to standardize practices in some of the forensic sciences and the medical examiner system, most forensic sciences have not identified or adopted standard best practices.

Additionally, there are no mechanisms to mandate common operational standards, required certification and accreditation of forensic disciplines. This is especially evident within state and local agencies (2009). From this recommendation the following evaluation questions concerning the forensics unit of KPD were developed for inclusion in the interviews with members of the forensics un:

1. Were there written standards for field investigations in the unit?

2. Did the standards cover all relevant practices related to evidence extraction, preservation, documentation and presentation?

3. What served as the basis for the standards?

4. Were these standards routinely updated?

5. Were these standards routinely disseminated?

Knoxville Police Department has its own Audits and Inspections Detail, which reviews all components and departments within the organization to ensure compliance 
with Standard Operating Procedures, General Orders, and standards put forth by the Commission on Accreditation for Law Enforcement Agencies (CALEA). The inspection process is designed to evaluate the need for training and to improve efficiency and effectiveness, with reviews being completed every three years (City of Knoxville, 2018).

The responsibilities and operating procedures the Forensics Unit at the Knoxville Police Department are detailed in the department's standard operating procedure, which were put into effect on June $2^{\text {nd }}, 1992$ and last revised with Chief of Police approval on March $1^{\text {st }}, 2017$ (Knoxville Police Department, 2017). According to this document, the following is the purpose of the Forensics Unit:

"It is the policy of the Forensics Unit to provide the people of the City of Knoxville with the best crime scene services available in a diligent, professional, and courteous manner, and to provide the members of the Knoxville Police Department and associated City of Knoxville offices with support services necessary to deliver their respective services to the people (p. 4)."

Furthermore, detailed responsibilities are provided in regard to field services,

firearms identification detail, identification detail, photography lab, and polygraph. Being most pertinent to the unit as a whole, the responsibilities for field services are as follows:

"Any substance or material recovered in connection with a civil or criminal investigation that could possibly aid in establishing the chain of events is considered physical evidence and shall be collected and processed relative to established procedures. All evidentiary items, substances, or materials shall be collected, maintained, and presented consistent with the professional standards established by the Knoxville Police Department directives, procedures, and/or regulations, legal sanctions, judiciary actions, and case holdings (p. 4)."

Individual sections of the policies and procedures are dedicated to each function within the unit with detailed instructions as to how evidence and information is collected 
and processed (i.e., field investigations, procedures for processing evidence, sealing/marking/labeling evidence, chain of custody, etc.).

For the purposes of this study, the focus is on those standards that relate to processing in the field and evidence extraction, preservation, documentation, and presentation. Regarding crime scene responsibilities the Knoxville Police Department Policies and Procedures stipulate that the initial member on the scene of any incident shall be responsible for securing the incident as found until relieved by authorized personnel for the purpose of collecting crime scene evidence. This member should not process, collect, or handle any evidence unless removal is necessary to preserve the evidence from outside sources (e.g., weather, gathering of a crowd). Every effort should be taken to protect physical evidence, particularly those items that may contain DNA evidence (e.g., by wearing gloves, avoiding sneezing or coughing, no eating/drinking/smoking at a crime scene). The scene should be secured and those entering and exiting should be documented.

Only those authorized to be at the scene may be present, including investigating members, forensic personnel, emergency medical personnel, and the scene supervisor; anyone else must be escorted at all times while in the crime scene. Information regarding the crime scene and any activities shall not be released to anyone except the lead investigator or the unit supervisor. All of the crime scene forensic staff members requested or assigned to the case must conduct all necessary collection and processing of evidence, including photographs, diagrams, sketches, preservation of evidence, and latent print processing; in addition, the investigating member shall be responsible for the atscene investigation. 
The Knoxville Police Department policies and procedures further require that when extracting evidence at the scene, processing and collection is conducted in ways that preserve the integrity and condition of the evidence, prevent the introduction of foreign materials, and ensure as complete a sample as possible. Biological DNA specimens with probative value is packaged in porous containers, and wet items should be allowed to air dry before they are packaged; very wet items may be placed in plastic bags or containers and air-dried as soon as possible. Physical evidence suck as liquid samples are placed in proper containers, placed in the Property Unit refrigerator, and shipped to the laboratory if necessary. Latent fingerprints are protected from any movement or action that might destroy or contaminate the prints. To prevent contamination, all forensic staff member are required to wear latex or nitrile gloves when handling items containing any suspected bodily fluids, as this type of evidence may provide trace DNA of forensic value.

Knoxville Police Department Policies and Procedures for documentation require all evidence is properly sealed in a timely manner, as well as marked and/or labeled to insure the proper identification at a later date. Evidence is packaged or placed in an appropriate container to ensure protection and items which cannot be marked are placed in an appropriate container which is sealed and marked. In order for physical evidence to be accepted by the courts, the chain of custody must be maintained. A complete listing of items is prepared and all evidence pertaining to the case placed with a crime scene action report in the master case file; this list includes (but is not limited to) a complete description of the item, the source, the name of the person who collected the item, and an assigned item number prefixed with "KPD". 
Evidence presentation is absolutely dependent on chain of custody. Within the Forensics Unit, all members are required, by department policy, to utilize a chain of custody form any time transfer of custody of physical evidence takes place. This form documents the full and continuous custody of all evidence handled by any member of the department; information includes the date and time of transfer, the receiving person's name and functional responsibility, reason for the transfer, and, when the evidence is transferred to a lab not within the department, the name/location of the laboratory, synopsis of the event, and the type of examination desired.

The department policies and procedures were developed based on best practices in the field and on CALEA recommendations, as part of the national law enforcement accreditation process. They cross reference with CALEA Standard Chapters 83 and 84 (Knoxville Police Department, 2017). By following these procedures, the Forensics Unit is able to successfully collect, process, and examine evidence that is paramount to the subsequent criminal investigations.

Since attitudes of personnel may affect the extent to which they incorporate best practices into the daily execution of their responsibilities, members of the forensics unit were asked their opinion on the implementation of uniform standards for forensic field investigation, as recommended by the National Institute of Justice (2009). All of the respondents agreed that uniform standards would be beneficial if implemented. One respondent stated

"I think it's good that they're doing something to, you know, make sure that wherever you might become a victim of crime in the United States that people who come to recover this evidence are properly trained and know what they're doing, and they're doing it according to a standard. That's not necessarily so across the country" [Respondent C] 
Opinions varied on how this implementation should occur, with some believing broad standards would be reasonable as "every crime scene is a little bit different" [Respondent A], and one respondent believing only certain standards could be implemented, saying “... certain things I think can't be standardized based off of, you know, budget constraints, staffing, things like that" [Respondent F]. One specifically mentioned state-level standards while two were in favor of national level standards. From this, one could infer that the unit members are open to the idea of state or national level standards, if they were to be developed. Their comments were in support of the need for standardization of some type within their profession.

The KPD had written standards to guide field investigations within the unit. The written policies governed all relevant practices related to evidence extraction, preservation, documentation and presentation. CALEA standards as well as best practices in the field served as the basis for the standards. They were updated regularly, though no less than every three years. Standards were regularly disseminated immediately following revisions to these standards. Additionally, members of the forensics unit expressed positive support for uniform standards and the need to make certain that regardless of where a crime occurred, evidence would be handled with the same degree of professionalism and appropriateness.

\section{Education}

As noted in the NIJ forensics report (2009, pp. 26-27),

“...training should move beyond transmittal of practices to education based on scientifically valid principles. In addition to the practical experience and learning acquired during an internship, a trainee should acquire rigorous interdisciplinary education and training in the scientific areas that constitute the basis for the particular forensic discipline and instruction on how to document and report the analysis." 
The review of unit practices with respect to this recommendation consisted of an assessment of the education levels of members of the forensics unit, information on their specific academic degrees and attitudes toward education and training for forensic investigators.

The Knoxville Police Department Policies and Procedures as applicable for the Forensics Unit require crime scene investigators to have a Bachelor's degree, preferably in the physical sciences though prior training and experience may be substituted on a case-by-case basis (Knoxville Police Department, 2017). The requirement for specific educational and/or experiential qualifications were consistent with the recommendations of the NIJ (2009) report on forensics. The survey administered to members of the KPD Forensics Unit found unit personnel to be in compliance with this policy and the NIJ recommendations. Specifically, as shown in Table 1 with self-reported information on experience and educational qualifications, most (71\%) of the members of the unit had 5 or more years of experience working in forensics investigation, with $57 \%$ in their current position for 5 years or more. Additionally, a majority of members of the unit $(71 \%)$ had completed an Associate's degree or higher, with $43 \%$ of the members of the unit holding a Bachelor's degree. Disciplines of their degrees included criminal justice, biology, political science, anthropology, and forensic sciences.

With respect to the importance of a degree in higher education, most unit members interviewed believed a minimum of a Bachelor's degree should be required. One recommended a minimum of a Master's degree, one stating a degree in higher education was not necessary, and one who vacillated between the importance of education and the importance of experience. 


\section{Table 1}

\section{Time in Forensics/Time in Current Position and Education Levels}

\begin{tabular}{|r|l|l|}
\hline & $\begin{array}{l}\text { Time in } \\
\text { Forensics }\end{array}$ & $\begin{array}{c}\text { Time in } \\
\text { Current } \\
\text { Position }\end{array}$ \\
\hline \begin{tabular}{r|r} 
Less than 12 \\
months
\end{tabular} & $14 \%(1)$ & $29 \%(2)$ \\
\hline $1-3$ years & $14 \%(1)$ & $14 \%(1)$ \\
\hline $3-5$ years & --- & -- \\
\hline $5-10$ years & $29 \%(2)$ & $29 \%(2)$ \\
\hline Over 10 years & $43 \%(3)$ & $29 \%(2)$ \\
\hline HS Diploma/GED & Respondents & \\
\hline Associates/Certificate & $14 \%(1)$ & \\
\hline Bachelor's Degree & $43 \%(3)$ & \\
\hline Master's Degree & $14 \%(1)$ & \\
\hline Doctoral Degree & --- & \\
\hline
\end{tabular}

One respondent stated

"... I think as courts are getting more detail-oriented in what they expect for testimony, that you need to have somebody who can articulate well and actually understand the dynamics of forensics rather than just the mechanics of it. And for that I think you need higher education" [Respondent G]

Relatedly, another respondent commented, "It's becoming more critical. With the CSI effect... there's a higher level of expectation that we're seeing in jury pools" [Respondent B]. The CSI effect apparently not only influences the discipline but the individual attitudes of forensic investigator with regard to educational requirements in their discipline. When asked if any educational degrees might more appropriate than 
others for work in forensics investigation, responses included biology, chemistry, anthropology, statistics, and criminal justice.

Regarding education versus experience, many respondents has similar responses. As explained previously, the majority of respondents thought education was an asset to those coming into the field, with one stating “... as we move forward, some type of higher education- not necessarily college, but specific training in that field- has become even more and more important" [Respondent B]. Another commented "Well, I think training and education should go hand in hand with the job that you're required to perform" [Respondent G].

With this in mind, some respondents believed education was not the most important thing to consider for the job. One example was the statements from Respondent C, who held a degree themselves:

"What's more important is that they came in with a general sense of what the scientific method is, what it means, and being able to adapt it to different circumstances" and

“There's formal education and there's applied intelligence. Show me what you know. I say a certificate, a college degree, gets you in the door, [but] results keep you in the room".

This experiential component theme was elaborated by other members of the unit, one of whom said "... you might have the on the job experience instead of the college degree, or you might have the college degree and not the experience you need" [Respondent E]. Another stated

"There's certain things only experience will teach you, and there's certain things that you're just going to get out of school more easily... certain crime scene investigation skills you have to learn on the job, so there's certain things that have to be taught through experience" [Respondent F] 
In summary, members of the forensics unit felt education and field experience and applied knowledge were equally important.

\section{Training}

Research questions related to training centered on the extent to which training was required as well as the nature of the requisite training. The research questions, as noted previously, were:

1. What training was required before an individual was allowed to participate in field investigations?

2. In what areas of traditional or nontraditional field methods have unit members been trained?

3. What routine training was administered?

4. Was yearly training required?

5. Does the training include interdisciplinary methods?

6. Was training with an outside agency required?

7. What was the level of knowledge of traditional vs. interdisciplinary methods among unit members?

The Knoxville Police Department Policies and Procedures contained training guidelines for members of the Forensics Unit (Knoxville Police Department, 2017). All members were required to complete an in-house training course presented by unit personnel and augmented, when available, by outside instruction. All members of the forensics unit were trained in processing crime scenes, including but not limited to the recovery of latent fingerprints and palm prints, recovery of foot, tool, and tire impressions, photographing crime and accident scenes, preparing crime or accident scene sketches, and collecting, preserving, and transmitting physical evidence, including DNA and biological materials. Additionally, members of the unit must satisfactorily complete 
the National Forensics Academy training program offered at the Law Enforcement Innovation Center (LEIC) in Oak Ridge, Tennessee, or a comparable training program.

The National Forensics Academy is an intensive 10-week training program designed to educate law enforcement agencies in evidence identification, collection, and preservation; participants engage with various disciplines through classroom instruction, lab activities, and field practicums through specialized courses which encompass 31 different methods of forensic evidence collection and investigation, including:

$\begin{array}{lll}\text { Bloodstain } & \text { Forensic Fire } & \text { Child Fatality } \\ \text { Pattern } & \text { Investigation } & \text { Manners of } \\ \text { Analysis } & \text { Latent } & \text { Death } \\ \text { Bombs, Booby } & \text { Fingerprint } & \text { Time Since } \\ \text { Traps, and } & \text { Processing } & \text { Death } \\ \text { Threats at the } & \text { Photography } & \text { Wound Pattern } \\ \text { Scene } & \text { (Digital and } & \text { Interpretation } \\ \text { Crime Scene } & \text { Videotaping) } & \text { Forensic } \\ \text { Management } & \text { Post-blast } & \text { Anthropology } \\ \text { Computer } & \text { Investigation } & \text { Bone Scatter } \\ \text { Sketching and } & \text { Postmortem } & \text { Search } \\ \text { Mapping, and } & \text { Fingerprinting } & \text { Forensic } \\ \text { Total Station } & \text { Serial Number } & \text { Entomology } \\ \text { Courtroom } & \text { Restoration } & \text { Forensic } \\ \text { Testimony } & \text { Shooting } & \text { Odontology } \\ \text { Criminal } & \text { Incident } & \text { Forensic } \\ \text { Investigative } & \text { Reconstruction } & \text { Osteology } \\ \text { Analysis } & \text { Trace Evidence } & \text { Human } \\ \text { DNA } & \text { Death } & \text { Remains } \\ \text { Firearms and } & \text { Investigation } & \text { Recovery } \\ \text { Toolmark } & \text { Autopsy } & \\ \text { Identification } & \text { Bone Trauma } & \\ \text { Footwear and } & \text { Burned Bone } & \\ \text { Tire } & & \\ \text { Impressions } & & \end{array}$

(Law Enforcement Innovation Center, 2018). In addition, training must be sufficient to ensure development of specific skills needed to perform the necessary tasks of forensic 
investigation. This requirement sets this unit apart from others around the country, as unit members are quickly exposed to a variety of interdisciplinary techniques and learn to become familiar with disciplines that normal law enforcement/forensics unit training do not cover, if that training is even administered at all. Furthermore, as a component of yearly in-service training, the Forensics Unit provided refresher training to each investigator in the area of crime scene processing, this training was designed to improve the knowledge of each investigator with respect to new laboratory capabilities, equipment, and examination techniques.

The basic and in-service training requirements for the KPD Forensics Unit appear to meet the recommendations of the NIJ forensic report (2009) which stated

“...training should move beyond transmittal of practices to education based on scientifically valid principles (...). A trainee should acquire rigorous interdisciplinary education and training in the scientific areas that constitute the basis for the particular forensic discipline and instruction on how to document and report the analysis".

Members of the forensics unit were asked to report on formal training they had received while working with or in preparation of working with the forensics unit. Table 2 presents the areas in which respondents had received formal training. A majority (86\%) had received training in bloodstain pattern analysis, with $71 \%$ having received training in ballistics, mapping/3D mapping, DNA recovery, toolmark identification, and trace evidence collection. Slightly more than one half $(57 \%)$ had received training in forensic anthropology and forensic entomology, with a total of $43 \%$ of the respondents with training in azimuth baseline mapping and fingerprint analysis, and 14\% with training in CODIS, odontology, and total station mapping. 


\section{Table 2}

\section{Forensics Unit Members Specialty Training}

\begin{tabular}{|c|c|}
\hline & $\begin{array}{c}\text { Training Received } \\
\text { and Percentages }\end{array}$ \\
\hline Bloodstain Pattern Analysis & $86 \%(6)$ \\
\hline Crime Scene Mapping & $71 \%(5)$ \\
\hline DNA Recovery & $71 \%(5)$ \\
\hline Toolmark Identification & $71 \%(5)$ \\
\hline Trace Evidence Collection & $71 \%(5)$ \\
\hline Ballistics & $57 \%(4)$ \\
\hline Mapping/3D Mapping & $57 \%(4)$ \\
\hline Forensic Anthropology & $57 \%(4)$ \\
\hline Forensic Entomology & $57 \%(4)$ \\
\hline Avimuth Baseline Mapping & $43 \%(3)$ \\
\hline Fingerprint Analysis & $43 \%(3)$ \\
\hline Combined Index DNA System (CODIS) & $14 \%(1)$ \\
\hline Total Station Mapping & $14 \%(1)$ \\
\hline Forensic Odontology & $14 \%(1)$ \\
\hline Zooarchaeology & --- \\
\hline Geographic Information System (GIS) & --- \\
\hline Forensic Botany & --- \\
\hline
\end{tabular}

When asked to list any national certifications in a forensic-related discipline they

might have, the National Forensics Academy was listed, with one individual holding a certification as a Crime Scene Analyst. Members of the unit clearly are receiving the varied training recommended by the National Institute of Justice (2009). As one respondent claimed,

"there really shouldn't be any (difference), because if you follow the scientific method and a discipline of collection and documenting, it's just a question of the venue is different, okay... there really shouldn't be a difference to the methodology" [Respondent C] 
Another stated "it's important for everybody to have a general knowledge of what can be utilized, and you know when to call for help from an expert where that's all they do in their job" [Respondent F]. In general, it seems that the unit members believed that they should be familiar with interdisciplinary methods, if only to be able to recognize what evidence should be collected for submission to a specialist.

When asked what their personal responsibilities were when they arrived and processed a crime scene, every respondent, including the supervisors, gave a version of the same response. Because of the size of the unit, any member, even those in supervisory positions, may need to process a crime scene from "beginning to end". Relatedly, one supervisor stated "Yes, I'm currently a sergeant over the unit, but I have to be capable of doing anything in the field that the techs do" [Respondent B]. In general, unit members were responsible for securing the scene, intensive documentation, photography, fingerprinting, evidence collection, and submitting evidence to confiscations. This could vary based on the nature of the crime scene, type of crime, number of unit members available, etc.

Due to the small size of the unit, perceptions of personnel responsibilities and characteristics of the workload of unit members was particularly significant. Many respondents stated their duties in the course of an investigation depended primarily on the characteristics of the scene they were called to and how many people were on duty to work that scene. Documentation of evidence came up in almost every interview as an essential duty when performing a forensic investigation, with one respondent saying "I think, just like a real estate agent would say location, location, location, in crime scene investigation it's document, document, document" [Respondent A]. This vital function was reflected in various responsibilities such as photography which was a major 
responsibility of this unit. Photographing the scene on arrival and then again with evidence placards, before collection of the evidentiary items could begin was mentioned as one of their most important duties. Given the size of the unit and the responses of unit personnel, it appeared that everyone in the unit was expected to be proficient in multiple areas of forensic investigation. The multi-disciplinary training therefore matched and met the needs of the unit as well as meeting the standards set forth by the National Institute of Justice (2009).

\section{Unit Culture}

The culture of an organization is important to the performance of members of that organization. As noted in a prior section, the following research questions were addressed:

1. How does rank influence one's level of involvement at the scene?

2. How do civilian responsibilities differ from officer responsibilities in terms of unit functions?

3. What is the nature of the interactions between officers and civilians?

4. Are members of the unit engaged with one another?

5. Was there encouragement and good rapport between unit members?

Both the survey and interviews conducted with members of the forensics unit were directed toward determining the extent of unit cohesiveness, confidence in unit members, nature of interactions between unit members, member perceptions of the unit, and openness to improvement/change. Table 3 contains the findings of this portion of the evaluation.

All respondents strongly agreed they felt comfortable interacting with individuals in the unit possessing a higher rank. This may be related to the small size of the unit which results in limited specialization among unit members. When asked what their 
Table 3

\section{Perceptions of Unit Cohesiveness}

\begin{tabular}{|c|c|c|c|c|c|}
\hline & \multicolumn{5}{|c|}{ Responses } \\
\hline & Strongly disagree & Disagree & $\begin{array}{c}\text { Neither agree nor } \\
\text { disagree }\end{array}$ & Agree & Strongly agree \\
\hline \multicolumn{6}{|l|}{$\begin{array}{l}\text { Unit } \\
\text { Cohesiveness }\end{array}$} \\
\hline $\begin{array}{r}\text { Interaction with } \\
\text { higher rank }\end{array}$ & --- & --- & --- & -- & $100 \%(5)$ \\
\hline $\begin{array}{r}\text { Unit not doing its } \\
\text { best }\end{array}$ & $40 \%(2)$ & $20 \%(1)$ & --- & $20 \%(1)$ & $20 \%(1)$ \\
\hline $\begin{array}{c}\text { Satisfied with } \\
\text { investigation }\end{array}$ & -- & $20 \%(1)$ & $20 \%(1)$ & $20 \%(1)$ & $40 \%(2)$ \\
\hline \multicolumn{6}{|l|}{$\begin{array}{l}\text { Confidence in } \\
\text { Others }\end{array}$} \\
\hline $\begin{array}{r}\text { Adequate } \\
\text { education and } \\
\text { training }\end{array}$ & --- & $20 \%(1)$ & $20 \%(1)$ & $60 \%(3)$ & \\
\hline $\begin{array}{r}\text { Coworkers } \\
\text { adequate } \\
\text { education/training }\end{array}$ & --- & $20 \%(1)$ & $20 \%(1)$ & $20 \%(1)$ & $40 \%(2)$ \\
\hline $\begin{array}{r}\text { Those in charge } \\
\text { fully trained }\end{array}$ & --- & --- & --- & $14 \%(1)$ & $86 \%(5)$ \\
\hline $\begin{array}{r}\text { Department funds } \\
\text { training }\end{array}$ & --- & --- & $20 \%(1)$ & $20 \%(1)$ & $60 \%(3)$ \\
\hline \multicolumn{6}{|l|}{$\begin{array}{l}\text { Openness to } \\
\text { Reform }\end{array}$} \\
\hline $\begin{array}{l}\text { Willing to learn } \\
\text { interdisciplinary }\end{array}$ & --- & --- & --- & $14 \%(1)$ & $86 \%(5)$ \\
\hline $\begin{array}{r}\text { Would become } \\
\text { certified }\end{array}$ & --- & --- & $14 \%(1)$ & --- & $86 \%(5)$ \\
\hline $\begin{array}{r}\text { Current standards } \\
\text { and protocol }\end{array}$ & --- & $20 \%(1)$ & --- & $20 \%(1)$ & $60 \%(3)$ \\
\hline
\end{tabular}

personal responsibilities were when they arrived and processed a crime scene, sworn, civilian and supervisory personnel reported they were responsible for processing the crime scene "beginning to end". In general, unit members were responsible for securing the scene, intensive documentation, photography, fingerprinting, evidence collection, and submitting evidence to confiscations.

While the respondents reported ease of interaction between individuals of varied ranks and statuses within the unit, not all members were in agreement that the unit was performing at "level best". Additionally, no agreement was apparent when asked 
whether or not they were satisfied with investigations conducted within the unit. This suggests that while there may be a strong need for members in the unit to perform as a team, their standards for what constitutes "good" unit performance and how "satisfied" they are with unit performance are not clear.

Some of the satisfaction with unit performance and investigations may be the result of confidence in the training and/or quality of training of members of the unit. Most respondents (80\%) agreed they had been provided with adequate education and training (both inside and outside of the department) to perform their jobs to the best of their abilities and that the department provided sufficient funds for outside training $(80 \%)$.

Additionally, all members of the unit (100\%) agreed that those individuals "in charge" of the unit should be fully trained, and most (60\%) of the members felt that their coworkers had adequate training/education.

Finally, a majority $(80 \%)$ of respondents agreed the current standards and policies regarding forensic investigation in their department followed the most stringent standards and protocol available. Furthermore, a majority (86\%) also strongly agreed they would become nationally certified if given the option to do so and another majority ( $86 \%)$ strongly agreed they would be willing to learn and implement new forensic techniques that utilized an interdisciplinary approach if they were shown to benefit forensic investigations. Overall, members of the unit were open to change as it related to national certification and new interdisciplinary forensic techniques. However, interest in new methods and techniques was tempered by the need to believe the new methods would be beneficial. 
Overall, the individuals in the unit exhibited confidence in themselves and their education and training as well as the training and education of their co-workers and felt that those "in charge" of the unit should be fully trained. A majority reported they would they would seek certification if given the opportunity. Most agreed they had been provided with adequate education and training both inside and outside of the department, and that the department provided sufficient funds for outside training. In spite of their confidence in their knowledge and that of other members of the unit, some members of the unit did not seem to believe the unit was functioning with peak performance.

Respondents were asked about the social, professional, and/or personal environment. Overall, most respondents believed the unit worked well together and everyone got along with one another. In terms of the professional environment one respondent stated:

"Knoxville's a really good place to get a lot of training and we're seeing a cycle of about three to five years of people coming in and then moving on to somewhere else...it's about $75 \%$ to $25 \%$ sworn. That's kind of odd for most law enforcement agencies, they're either all sworn or they're all not non-sworn, so that gives us a new obstacle to try and overcome too, because it's very easy for the non-sworn to feel like they're being treated differently..." [Respondent B]

Many respondents replied they felt comfortable going to their supervisors if they encountered any type of issue (be it personal or job-related), with one saying "Just today I had a question and my Lieutenant was here and was like 'well, go about it like this and if you have problems, call me'... so that's the easiest part" [Respondent E].

Diversity among personnel within the unit was mentioned up by two respondents, both sharing the same sentiment that diversity as a whole is lacking within the unit, with one replying “...I don't know that we're very diverse, I mean we're from different areas, but like racially and things like that, it's not a very diverse unit in that respect..." 
[Respondent F]. Although many in the unit were satisfied, two respondents brought up a difference in age as creating issues for them within the unit, with one saying "... the field today is staffed with people a lot younger than me, who have a different perspective on work ethics, or life, than I do..." [Respondent G] and the other stating "it's that whole different, entitlement generation, and they work for themselves" [Respondent A].

When asked what characteristics made for a "good forensic investigator", respondents reported mental stability, leadership potential, and detail-oriented. Specifically, one respondent mentioned individual fortitude stating that in this profession, people can be well-suited in many ways but there was need for "mentally balanced and stable people that can handle death, destruction, mayhem" [Respondent C]; in addition, another respondent stated “... in my profession we can’t be leading and directing. Everyone has to be a leader, because everyone most of the time are working by themselves" [Respondent G]. Members of the unit were consistent in their belief that staff within the unit possessed these qualities.

In regard to background, one respondent stated that "You have to have, for our job, you have to know a little bit of everything to be able to do our job" [Respondent E], with another saying a "... science background is probably a good way to go" [Respondent D]. This description fits the majority of the unit, when considering the education and training that members have received. In addition, knowing when to call in an expert is essential for this unit, as they rely on outside resources for forensic processing that is outside their expertise. Overall, these characteristics identified come together to describe the type of person who would be successful in the field, at least from the point of view of these particular unit members. 
Problems are likely to be encountered within any type of workplace environment, as mentioned with the apparently younger/older member disconnect; however, it seems that the unit as a whole works cohesively and everyone feels comfortable communicating with each other regardless of rank or status. The members share many of the characteristics they used to describe "good forensic investigators" and did not seem to be overwhelmed by their workload and their responsibilities on scene. Overall, one could conclude that the unit operates smoothly from a social, professional, and/or personal standpoint.

In regard to training confidence, Knoxville is unique in the fact that members of the forensics unit have easy access to one of the most comprehensive forensic training programs in the United States. From the data gathered, the unit seems to have familiarity with both traditional and interdisciplinary forensic disciplines. Unit members were very open and forthcoming with their knowledge base or lack thereof and seemed to view both sides of forensic disciplines as important and worth recognizing. Possibly due to the high workload of the unit and the occasional necessity of only one member working an entire scene from beginning to end, it seemed as if members may have been trained in more areas than individuals may be from other units, but this is completely speculative. In summary, unit members appear to be very well trained and knowledgeable in multiple areas of forensic expertise.

Finally, when assessing their openness to reform, unit members seem open not only to the possible implementation of state or national level standards, but also to the incorporation of interdisciplinary techniques in traditional forensic investigation. In addition, most of the unit members were supportive of higher educational requirements for those hired into a forensics unit. The interesting debate here comes with the dialectic 
of education vs. experience, as education could be viewed as higher education or extensive training with courses such as the National Forensics Academy. The recognition as both being an asset, however, indicates that members of this unit are open to reform in many of the areas this study sought to bring attention to.

\section{National Sample Comparison}

Findings from the current research were compared to findings from a national sample of Forensics Units (Rausch, 2015). The comparison suggests that the Knoxville Police Department meets or exceeds the benchmarks found in the prior research.

Written policies and procedures. Regarding standards, the Knoxville Police Department had a policy on standards and/or best practices, placing it in the majority of the baseline, in which $75.3 \%$ of agencies responded that they did have such a policy.

Training and education. The Knoxville Police Department requires all members of the forensics unit have pre-service training prior to their assignment to the unit and, thereafter, in-service training on an annual basis. A majority of the forensics units in the national sample (73.5\%) required some type of pre and in-service training. While the Knoxville Forensics Unit requires outside training, a majority of agencies in the national sample $(75.3 \%)$ do not.

Most departments in the national sample (90.2\%) provided funding for outside training, as does the Knoxville Police Department. In terms of training in specific forensic techniques, the Knoxville Police Department had higher rates of training than the baseline sample in azimuth baseline mapping, forensic anthropology, forensic entomology, and toolmark identification. Rates were too low for an accurate determination on odontology and total station mapping. Knoxville Police Department 
Training matched the baseline in ballistics, bloodstain pattern analysis, CODIS, crime scene mapping, DNA recovery, fingerprint analysis, and trace evidence collection. In addition, the department does utilize outside assistance, matching the baseline, in which $92.9 \%$ of units responded the same. Lastly, with respect to national certification, the Knoxville Police Department does not require this level of certification for members of the forensics unit which was consistent with the baseline responses $(91.9 \%$ reported they do not require national certification). In summary, the Knoxville police department exceeded the rates set in the national sample for requiring outside training and met or exceeded national sample rates for most training in the specialized areas.

With respect to education, Knoxville's forensics unit requires a Bachelor's degree at time of hire, placing it above the baseline, where $57 \%$ of the agencies reported they only required a high school diploma. The Knoxville Police Department Forensics Unit equaled baseline representation with respect to the number of unit members having a Bachelor's degree. Within the Knoxville Police Department Forensics Unit, one member (14\%) had a Master's Degree, three members (43\%) had a Bachelor's Degree and one member (14\%) an Associate Degree. 


\section{CHAPTER VI}

\section{CONCLUSIONS AND RECOMMENDATIONS}

The goal of the current research was to evaluate the efficiency and effectiveness of the Forensics Unit of the Knoxville Police Department. Using the case study approach, the research compared findings concerning the operations of the KPD Crime Scene Unit with standard promulgated by the National Institute of Justice (2009), prior research on effective crime scene investigators, and national baseline information on the characteristics of Crime Scene Units (Rausch, 2015).

Limitations to this study are the standard limitations of a case-study approach. Since only one crime scene unit was analyzed, questions of representativeness of the population and therefore whether the findings can be generalized can be raised. As more units are analyzed, more generalized findings can be produced; in addition, greater detail is gathered from an in-depth qualitative approach. An additional limitation included a small sample size for the interviews and a limited response rate $(13 \%)$ to the patrol operations survey. To combat this, further exploration of larger units would create a larger sample size, and the response rate could be improved by lengthening the response time and changing the ways in which the survey is presented (e.g., announcing the survey through email multiple times, asking those in charge of patrol operations to inform their respective unit members, etc. Failure to include demographics in the patrol operations survey limited the ability to determine representativeness of the sample and therefore 
posed further limits on generalizability and should be included on future surveys. Lastly, lack of research regarding this subject area also hinders generalizability, as there is very little research exists regarding Forensics Units either on a national or single unit level, which can only be overcome by conducting more studies related to the function and structure of units across the United States. Nonetheless, as a "pilot" research of a sort, the limitations provide insights in to the conduct of more rigorous analyses in the future.

The current analysis found that the Knoxville Police Department Forensics Unit was performing effectively, professionally and perceived as making significant contributions to the department. Members of the agency, consumers of unit services, found the forensics unit to be performing with a high level of satisfaction. The respondents stated the services provided were sufficient for their needs, timely, thorough, contributed to case conversion/conviction, and maintained good relationships with those outside the department. Additionally, respondents to the user survey believed members of the unit were adequately trained. The only "issue" identified through this survey was that a majority of the respondents felt the unit was not adequately staffed, which affected the unit's ability, in some instances, to respond in a timely manner.

The forensics unit was governed by standards that were written and routinely reviewed and updated. The standards were compliant with CALEA standards as well as the recommendations of the National Institute of Justice, National Research Council publication (2009). The standards were thorough in that they addressed relevant practices for evidence extraction, preservation, documentation, and presentation. Asked to provide their perspective on the implementation of uniform national standards for forensic field investigation, the members of the unit agreed that uniform national standards would be beneficial. The Knoxville Police Department Forensics Unit was 
similar to other forensics units sampled in a national survey in that a majority of these units had written policies, procedures and standards for their forensics units.

The unit had policies that set minimum education requirements for unit members. These standards were consistent with best practices as outlined in the National Institute of Justice, National Research Council publication (2009) and were consistent with the educational requirements of other forensics units within the national sample (Rausch, 2015). Most of the KPD Forensics Unit members had an Associate's degree or higher, with almost half of the unit holding a Bachelor's degree. Disciplines of their degrees included criminal justice, biology, political science, anthropology, and forensic sciences. Many members of the unit agreed that at least a Bachelor's degree was needed for this field, citing the expectations for performance in the field and standards set forth by the courts. The members felt education was an important asset but considered field experience and applied knowledge as an additionally important component.

Training guidelines within the unit required training in the processing crime scenes, including recovery of latent fingerprints and palm prints, recovery of foot, tool, and tire impressions, photographing crime and accident scenes, preparing crime or accident scene sketches, and collecting, preserving, and transmitting physical evidence, including DNA and biological materials. Members were also required to complete the National Forensics Academy or a comparable program, with the NFA providing extensive interdisciplinary training (e.g., crime scene management, death investigation, forensic anthropology, forensic entomology, firearms and toolmark identification, etc.). Members of the unit were aware of both the traditional and interdisciplinary methods of forensic investigation and were willing to learn and implement more interdisciplinary methods if given the opportunity to do so. 
The training requirements for the KPD forensics unit were consistent with the recommendations of the National Institute of Justice, Research Council publication (2009). The training requirements additionally met or exceeded those reported by other agencies in the national sample. The KPD forensics unit training was especially strengthened by their proximity and access to the National Forensics Academy.

When considering unit culture, all members of the unit felt comfortable interacting and communicating with other members of the unit regardless of rank and believed all members of the unit were responsible for crime scene processing. Satisfaction with unit performance and crime scene investigation was not uniform and there seemed to be a slight disconnect between the older and younger members of the unit. Similarly, though all members of the unit had confidence in their own training and that of others in the unit and believed the police department provided sufficient funding for additional training.

While there are differing opinions among members of the unit, the final impression was the members believed the unit worked well together and everyone got along with one another. Perceptions of those who performed well at their jobs included those with mental stability, leadership potential, and were detail-oriented.

In conclusion, the recommendations for the Knoxville Police Department Forensics Unit that follow from the findings of this report are:

1. The Department should monitor the activities of the Forensics Unit to ensure unit personnel are carrying manageable caseloads. One response from a member of the unit stated that there are times when only one investigator is available, and in order to achieve high quality scene investigation and documentation there should be at least two 
investigators assigned to every case. Additionally, crime scenes should be investigated in a timely manner. Insufficient staff to make unit services available $24 / 7$ can inadvertently harm the quality of the crime scene investigation.

2. Related to monitoring of the activities of the Forensics Unit, the Knoxville Police Department should hire additional personnel as appropriate on a priority basis. A common response from other members of KPD was that the Unit was not adequately staffed.

3. The Forensics Unit should hire personnel with postsecondary education whenever possible. Not only does this represent the feelings of the unit personnel, this takes into account the recommendations from the NIJ report. The disciplines of these degrees could include both the social and natural sciences.

4. The Forensics Unit should continue to sustain high quality in-service and pre-service training for its personnel. KPD is better than most agencies at providing training that will ensure members are properly trained and should continue sending members to the National Forensic Academy to receive training in a multitude of forensic disciplines.

5. The Forensics Unit should continue to encourage personnel to participate in and make available specialized training. KPD provides funding for its personnel to attend outside training and should continue doing so. In addition, personnel should be encouraged to attend training related to the disciplines they were exposed to during the National Forensic Academy.

6. The Department and the Forensics Unit should continuously perform quality control on standards. The Audit and Inspections Detail should continue their review of the Standard Operating Procedures for overall quality control within KPD as a whole; in addition, the Forensics Unit should periodically review their standards to update as appropriate, considering the ever-changing nature of forensic investigation, specifically mentioned in the NIJ recommendations. 
7. The Forensics Unit should incorporate team exercises as part of training to strengthen unit cohesion. A common theme from personnel was a disconnect between certain members of the Unit; with so few personnel, this could easily become disruptive within the workplace and could have an effect on the ability of some to perform their job duties. By including these exercises, the Unit could work towards developing rapport and support between personnel.

8. The Forensics Unit should track cases to determine the percentage of cases handled by the unit that result in closed cases. At present, data on case outcomes that could be used to assess unit performance is not collected. Collecting this information could allow for outcome measures to be developed, possibly creating an opportunity for assessment on the effectiveness of physical evidence on successful case resolutions through plea bargaining and trials.

With this report, the crime scene unit of the Knoxville Police Department has information that can be used to develop or refine current policies and practices in order to ensure they are maintaining the highest possible standards in forensic investigation. The use of program evaluation in the department could be expanded to review other units and therefore to generate information which can be used in evidence-based decision-making.

As noted by Mears (2010), there are significant problems with respect to the state of research that contributes to evidence-based policy and programs. This research sought to inform the efficiency and effectiveness of crime scene investigation and forensic evidence processing through the application of program evaluation. The specific goal was to assess the performance of the Knoxville Police Department Forensics Unit but more generally, to contribute to the evolution of informed decision-making in criminal justice policy and practice through evidence-based research. 
Implications for the general academic community and law enforcement agencies across the United States are also worth considering. If anything, the interpersonal nature of the study provides a better means of communication between academics and practitioners, which has become increasingly necessary as preference for data-driven policies has grown. As mentioned previously, utilization of the methodological framework provides a template for implementation in other crime scene units nationally, possibly allowing for the creation of a nationwide database that could facilitate the national standardization of crime scene investigation. Should this standardization come to fruition, case law resulting from important court decisions could ensure that the "gold standard" of forensic evidence results in appropriate and warranted convictions.

Recommendations resulting from this study include many possible directions for future research. Additional evaluations of other units would increase the knowledge base of how these units operate, allowing for comparison on several levels; these include the differences between larger and smaller units, variation and impacts of standards, education, training, and national certification, and how all of this is influenced by the type of forensic investigations conducted by the units themselves. Understanding how a unit operates as a whole on a smaller, more detailed scale provides much needed insight on the current status of forensics in law enforcement as the importance of forensic evidence increases as a whole. Furthermore, adding elements to the methodology that provide more information on the standards, education, training, and national certification of these units could allow for more specific recommendations that could prove beneficial to each individual unit. Further usage of program evaluations of units differing in size and composition will eventually result in a template that is generalizable across jurisdictions of various sizes, possibly resulting in the creation of a national database that 
could allow research conducted in a more traditional sense and could also serve to support the creation of national standards for forensic investigation.

Overall, the results from this study have limitations as noted previously. However, the results can provide directions for future evidence-based assessment of programs and units within law enforcement agencies. Much decision-making within law enforcement specifically and criminal justice generally, is not evidence-based.

Improvements to the methodology that would strengthen the validity of the findings could promote more program evaluation and therefore, evidence-based analyses of programs and operations within criminal justice agencies. 


\section{REFERENCES}

Barker, Derek (2004). The Scholarship of Engagement: A Taxonomy of Five Emerging Practices. Journal of Higher Education, Outreach and Engagement, 9(2), 123138.

Beal, D. J., Cohen, R.R., Burke, M.J., \& McLendon, C.L. (2003). Cohesion and performance in groups: A meta-analytic clarification of construct relations. Journal of Applied Psychology, 88, 989-1004.

Black, B. (1988). Evolving legal standards for the admissibility of scientific evidence. Science, 239(4847), 1508-1512.

Boyer, Ernst L. (1990). Scholarship reconsidered: Priorities of the professorate. San Francisco, Jossey-Bass.

Burns, K.R. (2007). Forensic anthropology training manual (2 ${ }^{\text {nd }}$ Ed.). Upper Saddle River, NJ: Prentice Hall.

Christensen, A.M., \& Crowder, C.M. (2009). Evidentiary standards for forensic anthropology. Journal of Forensic Sciences, 54(6), 1211-1216.

City of Knoxville. (2018). Audits and inspections. Retrieved from www.knoxvilletn.gov/cms/one.aspx?portalid=109562\&pageid=192581.

Cohen, S. G. \& Bailey, D.E. (1997). What makes teams fork: Group effectiveness research from the shop floor to the executive suite. Journal of Management, 23:239-290.

Daubert v. Merrell Dow Pharmaceuticals, Inc., 509 U.S. 579 (1993).

Dirkmaat, D.C., Cabo, L.L., Ousley, S.D., \& Symes, S.A. (2008). New perspectives in forensic anthropology. American Journal of Physical Anthropology, 137(47), 3352.

Durnal, E.W. (2010). Crime scene investigation (as seen on TV). Forensic Science International, 199(1), 1-5.

Federal Rules of Evidence. (1975).

Frye v. United States, 54 App.D.C. 46, 293F. 1013 (1923). 
General Electric Co. v. Joiner, 522 US 136 (1997).

Giannelli, P.C. (1992). Scientific evidence in criminal prosecutions. Military Law Review, 137, 167-186.

Grivas, C.R., \& Komar, D.A. (2008). Kumho, Daubert, and the nature of scientific inquiry: Implications for forensic anthropology. Journal of Forensic Sciences, 53(4), 771-775.

Hanley, J.R., Schmidt, W.W., \& Nichols, L.D. (2011). Introduction to criminal evidence and court procedure (7th Ed.). Richmond, CA: McCutchan Publishing Corporation.

James, S.H., \& Nordby, J.J. (Eds.). (2005). Forensic science: An introduction to scientific and investigative techniques (2nd Ed). Boca Raton, FL: CRC Press.

Jobling, M.A., Hurles, M.E., \& Tyler-Smith, C. (2004). Human Evolutionary Genetics. New York, NY: Garland Science.

Kelty, S.F., Julian, R., \& Robertson, J. (2011). Professionalism in crime scene examination: The seven key attributes of top crime scene examiners. Forensic Science Policy \& Management: An International Journal, 2(4), 175-186.

Knoxville Police Department. (2015). Knoxville Police Department 2015 Annual Report. Retrieved from www.knoxvilletn.gov/userfiles/servers/server 109478/file/police/kpd annualrepo rt2015.pdf.

-----. (2016). Knoxville Police Department 2016 Annual Report. Retrieved from www.knoxvilletn.gov/userfiles/servers/server_109478/file/police/kpd_annualrepo rt2016.pdf.

-----. (2017). Knoxville Police Department 2017 Annual Report. Retrieved from www.knoxvilletn.gov/userfiles/servers/server_109478/file/police/kpd_annualrepo rt2016.pdf.

Kort-Butler, L.A. (2016). Content analysis in the study of crime, media, and popular culture. In Oxford Research Encyclopedia of Criminology.

Kozlowski, S.W.J. \& Bell, B.S. (2003). Work groups and teams in organizations. IN W.C. Forman, D. R. Ilgen, \& R. J. Klimoski (Eds.). Handbook of psychology: Industrial and organizational psychology, Vol. 12, 333-375. London: Wiley.

Kumho Tire Co. v. Carmichael, 526 U.S. 137 (1999). 
Larson, D.O., Vass, A.A., \& Wise, M. (2011). Advanced scientific methods and procedures in the forensic investigation of clandestine graves. Journal of Contemporary Criminal Justice, 27(2), 149-182.

Law Enforcement Innovation Center. (2018). UT national forensic academy- 10 week program. Retrieved from http://leic.tennessee.edu/home/training/forensictraining/national-forensic-academy.

Ludwig, A., Edgar, T., \& Maguire, C.N. (2014). A model for managing crime scene examiners. Forensic Science Policy \& Management: An International Journal, 5(3-4), 76-90.

Lynch, S.D., Webb, I., \& Ferguson, R. (2001). Knoxville police department: To protect and serve 1849 to 2001. Knoxville, TN: Turner Publishing Company.

Marks, M.A., Mathtieu, J.E., \& Zaccaro, S.J. (2001) A temporally based framework and taxonomy of team processes. Academy of Management Review, 26(3): 356-376.

Mathieu, J.E., Gilson, L.L., \& Ruddy, T.M. (2006). Empowerment and team effectiveness: An empirical test of an integrated model. Journal of applied Psychology, 91: 97-108.

McCormick, M. (1982). Scientific evidence: Defining a new approach to admissibility. Iowa Law Review, 67(879), 879-916.

McGrath, J.E. (1964). Social psychology: A brief introduction. New York: Holt, Rinehart \& Winston.

McNamara, C. (2017). Basic Guide to Program Evaluation (Including Outcomes Evaluation. Retrieved from https://managementhelp.org/evaluation/programevaluation-guide.htm.

Mears, D.P. (2010). American criminal justice policy: An evaluation approach to increasing accountability and effectiveness. New York, NY: Cambridge University Press.

Mears, D.P., \& Barnes, J.C. (2010). Toward a systematic foundation for identifying evidence-based criminal justice sanctions and their relative effectiveness. Journal of Criminal Justice, 38(4), 702-710.

National Institute of Justice. (2009). Strengthening forensic science in the United States: A path forward. Washington, D.C.: National Research Council.

-----. (2011). Death investigation: A guide for the scene investigator. Washington, D.C.: National Research Council. 
----- (2013). Crime scene investigation: A guide for law enforcement. Washington, D.C.: National Research Council.

National Research Council. (2005). Improving evaluation of anticrime programs. Washington, DC: The National Academies Press.

Pepper, I.K. (2005). Crime scene investigation: methods and procedures. New York, NY: Open University Press.

Rausch, C. (2015). Interdisciplinary practices in forensics within American law enforcement: The international context. GTSF Journal of Law and Social Sciences, 4(2), 1-11.

Ravasi, E. and Schultz, M. (2006). Responding to organizational identity threats: Exploring the role of organizational culture. Academy of Management Journal, 49(3), 433-458.

Saks, M.J., \& Koehler, J.J. (2005). The coming paradigm shift in forensic identification science. Science, 309(5736), 892-895.

Sherman, L., Gottfredson, D., MacKenzie, D.L., Eck, J., Reuter, P., \& Bushway, S.D. (1998). Preventing crime: What works, what doesn't, what's promising (Research in Brief). Washington, DC: U.S. Department of Justice.

Small, Priya (2012, January 8). Four differences between research and program evaluation. Retrieved from https://managementhelp.org/blogs/nonprofit-capacitybuilding/2012/01/08/four-differences-between-research-and-program-evaluation/.

Snow, C.C. (1982). Forensic anthropology. Annual Review of Anthropology, 11, 97-131.

Swanson, C.R., Chamelin, N.C., Territo, L., \& Taylor, R.W. (2012). Criminal Investigation (11th ed.). New York, NY: McGraw-Hill.

United States Government Accountability Office. (2012). Designing evaluations. Retrieved from https://www.gao.gov/assets/590/588146.pdf.

-----. (2017). Program evaluation: Annual agency-wide plans could enhance leadership support for program evaluations. Retrieved from https://www.gao.gov/assets/690/687526.pdf.

Vito, G.F., \& Higgins, G.E. (2015). Practical program evaluation for criminal justice. Waltham, MA: Elsevier.

Welbourne, T. M., Johnson, D.E., \& Erez, A. (1998). The role-based performance scale: Validity analysis of a theory-based measure. Academy of Management Journal, $41,540-555$. 
Wiersama, J., Love, J.C., \& Naul, L.G. (2009). The influence of the Daubert guidelines on anthropological methods of scientific identification in the medical examiner setting. Hard Evidence: Case Studies in Forensic Anthropology, Prentice Hall, New Jersey, 80-90. 


\section{APPENDICES}

\section{Appendix A}

\section{Department Survey Questions}

1) Are you aware that the Knoxville Police Department has a dedicated Forensics Unit? Yes/No

2) Are you aware that the KPD Forensics Unit provides the following services: (select all that apply)?
a. Field Services (including collecting/processing/submitting evidence and photograph at the scene)
b. Firearms Identification Detail
c. Identification Detail
d. Photography Lab
e. Polygraph Detail

3) Have you utilized the services provided by the Forensics Unit? Yes/No

4) Over the past year, how often have you utilized services provided by the KPD Forensics Unit?

(Respondent fill-in)

5) Which services did you utilize? (select all that apply)
a. Field Services
b. Firearms Identification Detail 

c. Identification Detail
d. Photography Lab
e. Polygraph Detail

6) What, if any, forensic-related service would you prefer to have provided by the KPD Forensics Unit?

(Respondent fill-in)

7) Do you believe that KPD Forensics Unit responds in a timely manner? Yes/No

8) Do you believe that the KPD Forensics Unit is thorough in the performance of their job duties?

$\mathrm{Yes} / \mathrm{No}$

9) Do you believe that the KPD Forensics Unit maintains good relationships with investigators and patrol?

Yes/No

10) Do you believe that the KPD Forensics Unit is adequately trained?

Yes/No

11) Do you believe that the KPD Forensics Unit has an adequate number of support staff? $\mathrm{Yes} / \mathrm{No}$

12) Do you believe that the KPD Forensics Unit significantly contributes to case conversion and conviction rates?

Yes/No 


\title{
Appendix B
}

\author{
Consent Form \\ Consent of Participation and Release of Findings \\ Department of Criminal Justice \\ University of Louisville
}

You are being invited to participate in a research study by answering the attached survey, participate in a personal interview, or observed as a means of participant observation. As a doctoral student in the Department of Criminal Justice at the University of Louisville, I am conducting my dissertation research on the structure and procedures of KPD's forensics unit. This study aims to discover information regarding education levels, training occurrences/subject areas, knowledge of interdisciplinary/traditional field methods, standards in the field, relations between officers/civilians, unit culture, and case progressions through the system utilizing both quantitative and qualitative methods. I believe this information is crucial due to the increasing reliance on forensic evidence for conviction in the courtroom.

The survey, interview, or observation concerns the training, policies, practices, and outside training of those involved in forensics within your department. There are no known risks for your participation in this research study. All responses will remain confidential in regard to your department. Information gathered will be analyzed through qualitative and quantitative procedures. The information collected may not benefit you directly; however, a copy of the results can be provided to you if desired. The information gathered from this survey may be helpful in developing linear national training standards for those involved with forensic investigation. Your completed survey and/or recording/interview notes will be stored in the Department of Criminal Justice, University of Louisville. The survey will take approximately 20 minutes to complete and the interview will last approximately thirty minutes. Interviews may be digitally recorded as allowable by local, state, and federal law.

This research is being funded by the National Institute of Justice, Award No. 2016-R2CX-0006. Individuals from the Department of Criminal Justice, the Institutional Review Board (IRB), the Human Subjects Protection Program Office (HSPPO), National Institute of Justice (NIJ), and other regulatory agencies may inspect these records. In all other respects, however, the data will be held in confidence to the extent permitted by law. Should the data be published, your identity will not be disclosed. Coded data will be archived with the National Archive of Criminal Justice Data.

Taking part in this study is voluntary. By completing this survey or participating in this interview, you agree to take part in this research study. You do not have to answer any questions that make you uncomfortable and may leave any of the questions blank and/or refuse to answer a question. You may choose not to take part at all. At any time, you may withdraw your consent to participate in this study; this includes exclusion of any previous information provided if you so desire. If you have any questions, concerns, or complaints 
about the research study, please contact Cassandra Rausch at (502) 852-8552. You may also contact the advisor of this research, Dr. Deborah Keeling, at (502) 852-0370.

If you have any questions about your rights as a research subject, you may call the Human Subjects Protection Program Office at (502) 852-5188. You can discuss any questions about your rights as a research subject, in private, with a member of the Institutional Review Board (IRB). You may also call this number if you have any other questions about the research and you cannot reach the research staff or prefer to contact someone other than the research staff. The IRB is an independent committee made up of people from the University community, staff of the institutions, as well as people from the community not connected with these institutions.

The IRB has reviewed and approved this research study. If you have concerns or complaints about the research or research staff and you do not wish to give your name, you may call 1(877) $852-1167$. This is a 24 -hour hotline answered by individuals who do not work at the University of Louisville.

Sincerely,

Cassandra Rausch

Graduate Assistant

Department of Criminal Justice

University of Louisville 


\section{Acknowledgement and Signatures}

This informed consent document is not a contract. This document tells you what will happen during the study if you choose to take part. Your signature indicates that this study has been explained to you, that your questions have been answered, and that you agree to take part in the study. You are not giving up any legal rights to which you are entitled by signing this informed consent document. You will be given a copy of this consent form to keep for your records.

Name (Please Print)

Signature

Date Signed

Thank you in advance for your time and effort if you choose to participate and for contributing to our knowledge on forensic investigation.

YES, I agree to participate in ALL COMPONENTS of this research study by completing a survey AND participating in an interview.

Signature

Date Signed

YES, I agree to participate in this research study by completing a survey or participating in an interview (please CIRCLE which component/s you consent to participate in).

Signature

Date Signed

NO, I decline to participate in this research study or have decided to end my participation.

Signature

Date Signed

PI Name (Printed)

PI Signature

Date Signed 


\section{Appendix C}

Unit Survey Questionnaire

\section{Survey Questionnaire- Knoxville Police Department Crime Scene Unit}

Age (circle one)

$18-24 \quad 25-34 \quad 35-44 \quad 45-54 \quad 55+$

Gender (circle one)

Male Female

Status (circle one)

Civilian Sworn Officer

Rank/Position:

How long have you worked in forensic investigation? (circle one)

Less than 12 months $\quad$ 1-3 years $\quad 3-5$ years $\quad 5-10$ years Over 10 years

How long have you been in your current position? (circle one)

Less than 12 months $\quad$ 1-3 years $\quad 3-5$ years $\quad-10$ years Over 10 years

If you have worked in forensics outside of KPD, what was your position and department?-

What is your highest level of education? (circle one)

HSD/GED Associate/Certificate Bachelor Master Doctoral

Which discipline/s are your degree/s in?

What forensic areas have you received training in? (circle all that apply)

Azimuth Baseline Mapping Ballistics Bloodstain Pattern Analysis CODIS

Crime Scene Mapping DNA Recovery Fingerprint Analysis Forensic

Anthropology Forensic Botany Forensic Entomology

Forensic Odontology GIS Toolmark Identification Total Station

Mapping/3D Mapping Trace Evidence Collection Zooarchaeology 
For the following questions, circle the number that best fits your opinion, with $1=$ strongly disagree, $2=$ disagree, $3=$ =neither agree nor disagree, $4=$ =agree, and $5=$ =strongly agree.

1) I feel comfortable interacting with individuals possessing a higher rank than me in my unit.

$\begin{array}{lllll}1 & 2 & 3 & 4 & 5\end{array}$

2) I feel that the current standards and policies regarding forensic investigation in my department follow the most stringent standards and protocol available.

$\begin{array}{lllll}1 & 2 & 3 & 4 & 5\end{array}$

3) I believe that I have been provided adequate education and training (both inside and outside of the department) to perform my job to the best of my ability.

$\begin{array}{lllll}1 & 2 & 3 & 4 & 5\end{array}$

4) I believe that my coworkers have been adequately educated and trained (both inside and outside of the department) to perform their jobs to the best of their abilities.

$\begin{array}{lllll}1 & 2 & 3 & 4 & 5\end{array}$

5) I sometimes worry that we aren't doing the best we can as a unit in regards to field investigations.

$\begin{array}{lllll}1 & 2 & 3 & 4 & 5\end{array}$

6) I believe that those in charge of the unit should be fully trained in the methods we use both in the field and in the laboratory.

$\begin{array}{lllll}1 & 2 & 3 & 4 & 5\end{array}$

7) I would be willing to learn and implement new forensic techniques that utilize an interdisciplinary approach if they were shown to benefit forensic investigations. 


$\begin{array}{lllll}1 & 2 & 3 & 4 & 5\end{array}$

8) I believe that the department provides adequate funding to attend outside training.

$\begin{array}{lllll}1 & 2 & 3 & 4 & 5\end{array}$

9) I would attempt to become nationally certified if I was given the option to do so.

$\begin{array}{lllll}1 & 2 & 3 & 4 & 5\end{array}$

10) Overall, I am completely satisfied with how our unit conducts forensic investigations.

$\begin{array}{lllll}1 & 2 & 3 & 4 & 5\end{array}$




\section{Appendix D}

Interview Guide

\section{Interview Guide- Knoxville Police Department Crime Scene Unit}

What is your perspective on higher education levels for those involved in forensic investigation?

-higher vs. lower

-higher requirements at time of hire?

-what disciplines are important

What is your perspective on the implementation of uniform standards for forensic field investigations?

-state vs. national

-blanket or crime-specific?

-what would your recommendations be in regard to the most important standards

Can you tell me what you know about traditional vs. interdisciplinary methods of forensic investigation?

-explain interdisciplinary if necessary

-is one better than the other?

-how would you feel about interdisciplinary incorporation of techniques; would it be beneficial or not?

What are your personal responsibilities when you arrive at a crime scene?

-during processing of a crime scene

-after processing of a crime scene

-after returning to the department

What, in your opinion, would you describe about the "culture" of your unit as a whole?

-“culture" meaning social, professional, and or personal environment 


\title{
CURRICULUM VITA
}

\author{
Cassandra C. Rausch
}

Department of Criminal Justice

701 Bluegrass Ave Louisville KY 40215

Cell Phone: 502-296-7644

2301 S. $3^{\text {rd }}$ Street

University of Louisville

E-mail: cassandra.rausch@louisville.edu

Louisville, KY 40292

\section{EDUCATIONAL BACKGROUND:}

University of Louisville Louisville, KY

2018

Ph.D. in Criminal Justice.

Dissertation: Furthering Understanding of Forensic Units: A Detailed Examination

of Knoxville Police Department's Crime Scene Unit.

Chair: Dr. Deborah Keeling.

Committee: Dr. Cherie Dawson-Edwards, Dr. Viviana Andreescu, and

Dr. Stuart Esrock.

University of Louisville Louisville, KY

2014

M.S. in Administration of Justice.

Thesis: Prevalence of Knowledge in Forensic Anthropological Field Methods

within Traditional Criminal Investigation.

Chairs: Dr. Deborah Keeling and Professor Philip DiBlasi.

Committee: Professor Michael Losavio.

University of Louisville Louisville, KY

B.A. in Anthropology- concentration in Natural Sciences.

Minor in Russian Studies.

\section{GRANTS AND GRANT REPORTS:}

2016 National Institute of Justice Graduate Research Fellowship in the Social and Behavioral Sciences. "Furthering Understanding of Forensic Units: A Detailed Examination of Louisville Metro Police Department's Crime Scene Unit”. \$32,000.

Dawson-Edwards, C., Tewksbury, R., Higgins, G.E., \& Rausch, C. (2014). Disproportionate contact in Kentucky: Statewide assessment report (Research report funded through the State of Kentucky's Office of Juvenile Justice and Delinquency Prevention). Frankfort, KY: Kentucky Department of Juvenile Justice.

\section{PEER-REVIEWED PUBLICATIONS:}

Rausch, C. (2015). Interdisciplinary practices in forensics within American law enforcement: The international context. GTSF Journal of Law and Social Sciences, 4(2), 1-11.

Rausch, C. (2015). Fundamentalism and terrorism. Journal of Terrorism Research, 6(2), 28-35.

\section{TEACHING EXPERIENCE:}

CJ 496: Death Investigation

CJ 355: Criminalistics

Course Facilitator

CJ 352: Sex Crimes 


\section{RESEARCH INTERESTS:}

Examination of standards, education, and training within Law Enforcement forensic units.

General policing practices and training.

Interdisciplinary cooperation in relation to field techniques of crime scene investigation.

Recovery methods and interpretation of remains from mass disasters (natural, terrorist, or accidental)

and mass graves.

Studies on the institutions of war, state-sanctioned violence, and mass murder.

Interaction with persons involved with the selling and/or consumption of drugs of abuse through

qualitative methodologies.

\section{OTHER PUBLICATIONS:}

Rausch, C. (2015). Genocide. In W. Jennings (Ed.), Encyclopedia of Crime and Punishment. Malden, MA: Wiley-Blackwell.

Keeling, D., Rausch, C., \& Masterson, J. (2015). International Policing. In W. Jennings (Ed.),

Encyclopedia of Crime and Punishment. Malden, MA: Wiley-Blackwell.

Rausch, C. (2015). My Lai Massacre. In S. Chermak \& F. Bailey (Eds.), Crimes of the Centuries: An Encyclopedia of Notorious Crimes, Criminals, and Criminal Trials in American History. Santa Barbara, CA: ABC-CLIO.

Rausch, C. (2015). Parker, Bonnie/Clyde Barrow. In S. Chermak \& F. Bailey (Eds.), Crimes of the Centuries: An Encyclopedia of Notorious Crimes, Criminals, and Criminal Trials in American History. Santa Barbara, CA: ABC-CLIO.

Rausch, C. (2015). Belle Gunness. In S. Chermak \& F. Bailey (Eds.), Crimes of the Centuries: An Encyclopedia of Notorious Crimes, Criminals, and Criminal Trials in American History. Santa Barbara, CA: ABC-CLIO.

\section{PRESENTATIONS:}

Rausch, C. (2017, March). Furthering Understanding of Forensic Units: Preliminary Findings. Panel, "Evaluation of Policing Practices"; research findings presented at the annual meeting of the Academy of Criminal Justice Sciences, Kansas City, MO.

Rausch, C. (2017, March). How to "Re"-Create Forensic Crime Scenes for Practical Law Enforcement and Forensic Education. Open seminar at the annual meeting of the Academy of Criminal Justice Sciences, Kansas City, MO.

Rausch, C. (2016, September). The Evolution of Student Learning Styles: Incorporating Practical Forensic Experience in the Criminal Justice Classroom. Panel, "Criminal Justice Pedagogy II"; research findings presented at the annual meeting of the Southern Criminal Justice Association, Savannah, GA.

Rausch, C. (2016, September). Creating "Crime Scenes" to Incorporate Practical Forensic Training within the Classroom. Poster Presentation; research findings presented at the annual meeting of the Southern Criminal Justice Association, Savannah, GA.

Rausch, C. (2016, March). Does the Drug Determine the Status? Discovering the "Drug Hierarchy" and Relationships between Drug Dealers. Panel and panel chair, "In-depth Examinations of Substance Abuse"; research findings presented at the annual meeting of the Academy of Criminal Justice Sciences, Denver, CO.

Rausch, C. (2016, February). Forensic Anthropological Field Methods: The Importance of Interdisciplinary Incorporation to Traditional Crime Scene Investigation. Young Forensic Scientists Forum, research findings presented at the annual meeting of the American Academy of Forensic Sciences, Las Vegas, NV.

Andreescu, V., Shon, L., \& Rausch, C. (2015, November). Heterosexism and Homophobia in the Russian Federation: Public Attitudes towards Sexual Minorities' Civil Rights. Poster Presentation; research findings presented at the annual meeting of the American Society of Criminology,

Washington, DC.

Rausch, C. (2015, September). "I've got a PhD in the Streets": Insider/Outsider Perspectives of a Drug Dealer. Panel, "Drug Use from the Users' Perspectives"; research findings presented at the annual meeting of the Southern Criminal Justice Association, Charleston, SC.

Rausch, C., Nelson, N., Redman, P., London, A., Cornett, S., Navarro, J., Nicholson, J, \& Higgins, E. (2015, September). Development of a Felony Criminal Mediation Program in Jefferson County, Kentucky. Roundtable Discussion; research findings presented at the annual meeting of the Southern Criminal Justice Association, Charleston, SC. 
Rausch, C. (2015, March). Standards, Education, and Training: An Assessment of Forensic Investigation Units in Kentucky, Indiana, and Tennessee. Panel, "Innovations in Law Enforcement"; research findings presented at the annual meeting of the Academy of Criminal Justice Sciences, Orlando, FL.

Rausch, C. (2014, November). Interdisciplinary Practices in Forensics within American Law Enforcement: The International Context. Research findings presented at the annual International Conference on Forensic Sciences and Criminalistics Research, Singapore.

- "Best Student Research Paper" Award

Rausch, C. (2014, September). Forensics and Law Enforcement: A National Survey Regarding Standards, Education, and Training. Panel, "Topics in Law Enforcement"; research findings presented at the annual meeting of the Southern Criminal Justice Association, Clearwater, FL.

Rausch, C. (2014, February). Genocide: Theories, Prevention, \& Prosecution. Panel and panel chair, "Theoretical Explanations of Criminal Behavior"; research findings presented at the annual meeting of the Academy of Criminal Justice Sciences, Philadelphia, PA.

\section{PROFESSIONAL MEMBERSHIPS (STUDENT):}

American Society of Criminology

American Academy of Forensic Sciences

Global Science and Technology Forum

Southern Criminal Justice Association

Academy of Criminal Justice Sciences

November 2015-present March 2015-present November 2014-present August 2014-present February 2014-present

\section{SERVICE:}

Site Selection and Awards Committee Member

Southern Criminal Justice Association

Article Editor

SAGE Open

Reviewer

Journal of Criminal Justice Education

Journal of Terrorism Research

School of Interdisciplinary and Graduate Studies

University of Louisville

Graduate Student Ambassador

Alpha Phi Sigma National Honor Society for Criminal Justice

President

\section{TRAINING AND EXPERIENCE:}

\section{Forensics}

National Forensics Academy Symposium

Short course through the Law Enforcement and Innovation Center at the

University of Tennessee: Nashville, TN. Training hours: 16.

National Forensics Academy Symposium

Short course through the Law Enforcement and Innovation Center at the University of Tennessee: Nashville, TN. Training hours: 16.

Independent Study ANTH 670/671: Forensic Archaeology

Data collection on the prevalence of knowledge in forensic anthropological

methods through a survey of Law Enforcement agencies across the United

States.

Lab Assistant

Archaeological Survey Building, University of Louisville.

Internship

Forensic Anthropology Center and Anthropological Research Facility,

University of Tennessee: Knoxville, TN.

Forensic Anthropology Field Methods

Short course through the University of Tennessee: Knoxville, TN. Training hours: 40.

Internship

Office of the Chief Medical Examiner: Louisville, KY.
Summer 2016-Spring 2016

Fall 2015-Spring 2016

May 2015-December 2016

April 2015-April 2016
January 2015

Fall 2013-Spring 2014

Fall 2012-Spring 2013

July 2012

May 2012

Spring 2012 
Responsible for estimation of age, sex, ancestry and stature; research leading to presentation of complete skeletal analysis and report.

\section{Academics}

Doctoral Student Summit

March 2016

Competitive program offered through the Academy of Criminal Justice

Sciences at the 2016 Annual Meeting in Denver, CO.

Publishing Academy

Competitive program offered through the School of Interdisciplinary and

Graduate Studies, University of Louisville.

Online Course Development

CJ 426: Violence in the United States. Department of Criminal Justice, University of Louisville.

Graduate Research Assistant

Department of Justice Administration, University of Louisville. Supervisor: Dr.

Cherie Dawson-Edwards.

Graduate Teaching Assistant Academy

Competitive program offered through the School of Interdisciplinary and

Graduate Studies, University of Louisville.

Proseminar in Teaching

Department of Justice Administration, University of Louisville.

Grant Writing Academy

Competitive program offered through the School of Interdisciplinary and

Graduate Studies, University of Louisville.

Graduate Research Assistant

Department of Justice Administration, University of Louisville. Supervisors:

Dr. Deborah Keeling and Dr. Cherie Dawson-Edwards.

Learning Assistant

ANTH 204: Introduction to Archaeology. Department of Anthropology,

University of Louisville.

\section{HONORARIES/AWARDS:}

Doctoral Student Summit

March 2016

Scholarship, Academy of Criminal Justice Sciences

Graduate Student Council Travel Award

Scholarship, \$350, University of Louisville School of Interdisciplinary and

Graduate Studies.

Graduate Network in Arts and Sciences Research Award

Scholarship, \$100, University of Louisville School of Interdisciplinary and

Graduate Studies.

Strategic Plan Tuition Award

Scholarship, University of Louisville School of Interdisciplinary and

Graduate Studies.

Best Student Research Paper

Spring 2016

Summer 2015

Fall 2014-Spring 2015

Fall 2014-Spring 2015

Fall 2014

Spring 2014

Fall 2013-Spring 2014

Fall 2012-Spring 2013

International Conference on Forensic Science and Criminalistics Research,

Singapore.

Alpha Phi Sigma National Honor Society for Criminal Justice.

Phi Kappa Phi National Honor Society.

Kenneth J. Marshall Outstanding Graduate Student Award

Departmental Award (Justice Administration), University of Louisville.

Sponsored Research Tuition Award

Scholarship, University of Louisville School of Interdisciplinary and

Graduate Studies.

Golden Key International Honor Society.

Dr. M. Celeste Nichols Professional Development Award

Scholarship, University of Louisville Women's Center.

November 2014

October 2014

May 2014

April 2014

Spring 2014

January 2014

October 2013 
Graduate Assistantship

University of Louisville Department of Justice Administration/Criminal Justice.

Lambda Alpha National Honor Society for Anthropology.
Spring 2013-present

Spring 2011 